\title{
Snowmelt Hydrology of a Sierra Nevada Stream
}

GEOLOGICAL SURVEY WATER-SUPPLY PAPER 1779-R

Prepared in cooperation with California Department of Water Resources

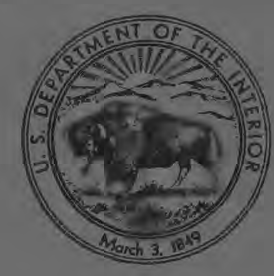




\section{Snowmelt Hydrology of a Sierra Nevada Stream}

By S. E. RANTZ

CONTRIBUTIONS TO THE HYDROLOGY OF THE UNITED STATES

GEOLOGICAL SURVEY WATER-SUPPLY PAPER 1779-R

Prepared in cooperation with California Department of Water Resources

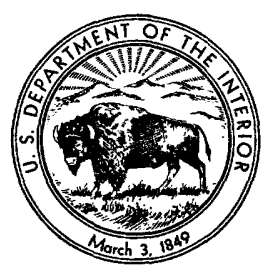




\section{UNITED STATES DEPARTMENT OF THE INTERIOR}

STEWART L. UDALL, Secretary

\section{GEOLOGIGAL SURVEY}

Thomas B. Nolan, Director 


\section{CONTENTS}

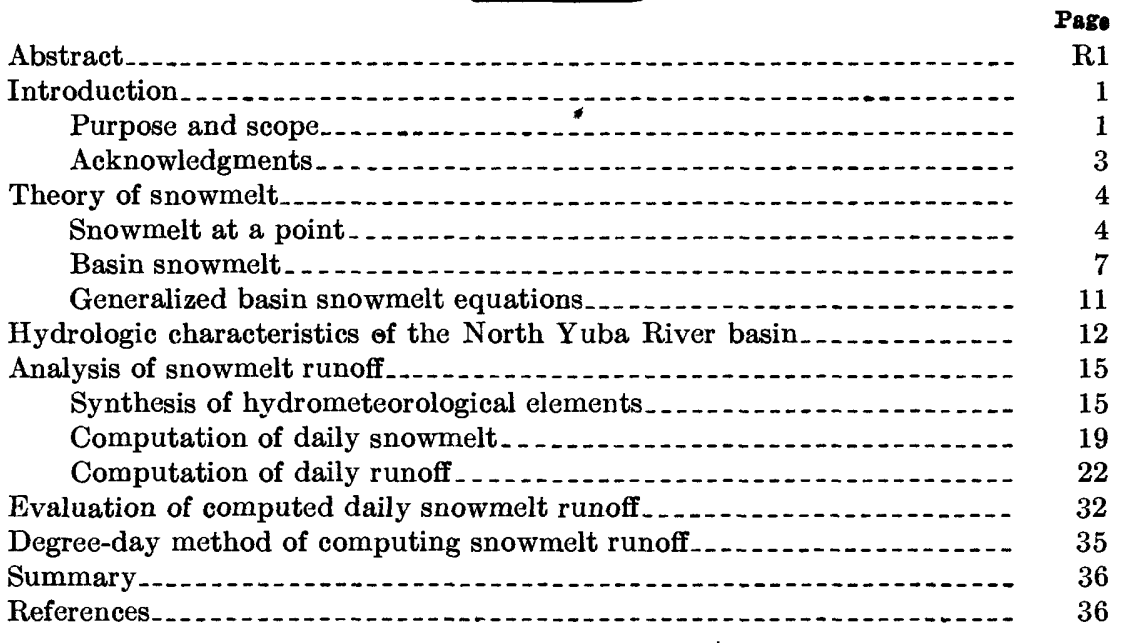

\section{ILLUSTRATIONS}

Figure 1. Location map showing report area

2. Maximum daily solar radiation at latitude of North Yuba River basin

3. Sketch map of North Yuba River basin upstream from Goodyears Bar

4. Area-altitude distribution for the North Yuba River basin....

5. Relation of water equivalent of snowpack to altitude, at start of melt season.

6. Relation between cloud cover and percent of maximum daily insolation at Davis, Calif., for period April 1 through June 30_

7. Variation of snow-surface albedo with time during the snowmelt season

8. Base-flow recession curve for North Yuba River below Goodyears Bar.

9. Relation of base flow to volume of "live" ground-water storage_

10. Daily distribution graph for North Yuba River below Goodyears Bar.

11. Synthesized and observed daily runoff during the snowmelt seasons, North Yuba River below Goodyears Bar 


\section{TABLES}

TABLE 1. Hydrologic characteristics of the North Yuba River basin...-

2. Snow-course data for the North Yuba River basin

3. Daily distribution of snowmelt and rainfall, North Yuba River

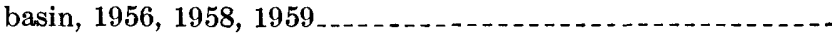

4. Daily infiltration and evapotranspiration loss for various condi-

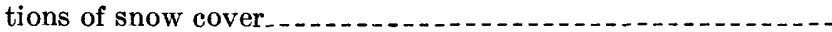

5. Synthesized and observed daily runoff, North Yuba River below Goodyears Bar, 1956, 1958, 1959_....... 29

6. Degree-day indices of runoff at snow laboratory basins........ 


\title{
CONTRIBUTIONS TO THE HYDROLOGY OF THE UNITED STATES
}

\section{SNOWMELT HYDROLOGY OF A SIERRA NEVADA STREAM}

\author{
By S. E. RaNTz
}

\section{ABSTRACT}

This report demonstrates a rational method of computing snowmelt runoff. The area utilized for this study was the North Yuba River basin upstream from the gaging station below Goodyears Bar, in the Sierra Nevada in California. The snowmelt formulas that were used had been previously arrived at during a Federal interagency snow investigation, conducted in small mountain study areas in western United States. These formulas are based on physical laws of heat exchange, and in them are incorporated constants that reflect the effect of such environmental influences as forest cover and basin exposure. The formulas were used to compute the daily magnitude of the various components of snowmelt; namely, shortwave and longwave radiation melt, convection melt, condensation melt, and rain melt. These melt components were then totaled and routed to the gaging station.

Three years were selected for study; the years 1956 and 1958 when the heaviest snowpack of the last decade occurred, and the year 1959 when one of the lightest snowpacks of recent years occurred. The snow-survey data collected in late March or early April of each of these years, and daily meteorological observations by the U.S. Weather Bureau during the ensuing 3-month snowmelt seasons, were used to compute synthetic records of daily discharge of the North Yuba River below Goodyears Bar. The computed hydrographs of snowmelt discharge for these 3 years showed satisfactory agreement with the recorded hydrographs, thereby attesting to the soundness of the method used.

Because few of the hydrometeorological elements needed for computing snowmelt are observed within the North Yuba River basin, it had been necessary in this study to transfer observations from nearby weather stations and to synthesize daily values of other required elements. Closer agreement between computed and observed hydrographs would undoubtedly have been attained had there been a more comprehensive network of hydrometeorological stations within the basin.

\section{INTRODUCTION}

\section{PURPOSE AND SCOPE}

Until recent years the problem of estimating snowmelt runoff from mountainous river basins was dealt with by using simple empirical relations, primarily because of a lack of adequate basic knowledge of the physical processes involved. The formulation of a rational 
method of solving the problem resulted from an intensive cooperative research program conducted during the years 1945-56, by the U.S. Army Corps of Engineers and the U.S. Weather Bureau. Other Federal agencies were minor participants in the program, and the author, as the representative of the U.S. Geological Survey, was one of the analysts assigned to the investigation.

The problem of evaluating snowmelt involves a consideration of all three processes of heat transfer: radiation, convection, and conduction. The relative importance of each of these processes is highly variable, depending upon conditions of weather and local environment. For example in late spring, given a clear day and fairly open terrain, radiation is the prime factor in the melting of snow. However, under conditions of heavy cloud cover or heavily forested terrain, radiation becomes a minor element. In exposed areas wind is an important element in the convection process; in heavily forested areas wind becomes a minor factor. It has been possible in the laboratory to derive general equations and theoretical coefficients for the evaluation of snowmelt at a point. However, to derive coefficients of basin snowmelt that would fill the need of the practicing hydrologist, it was necessary to instrument small study areas that sample diverse conditions of climate and topography. The cooperative research studies mentioned in the previous paragraph were made, therefore, at three intensively instrumented mountain sites, one of which was in the Sierra Nevada in California, another in the Cascade Mountains in Oregon, and the third in the Rocky Mountains in Montana. The study areas ranged in size from 4 to 21 square miles.

The purpose of this report is to present the results of a test of the general applicability of the formulas derived for the small study areas. The basin selected for the test was that of the North Yuba River upstream from the Geological Survey gaging station below Goodyears Bar, Calif. (fig. 1). This stream, draining an area of 245 square miles in the Sierra Nevada, was selected because it is free of regulation and diversion and because of the wide range in altitude of its watershed $(2,450$ to 8,590 feet). Three years were selected for study; the years 1956 and 1958 when the heaviest snowpack of the last decade occurred, and the year 1959 when one of the lightest snowpacks of recent years occurred. The snow-survey data collected in late March or early April of each of these years and daily meteorological observations by the Weather Bureau during the ensuing 3-month snowmelt seasons, were used in the formulas to compute synthetic values of daily discharge of North Yuba River at the gaging station. The synthesized hydrographs of snowmelt discharge for these 3 years showed satisfactory agreement with the recorded hydrographs. 


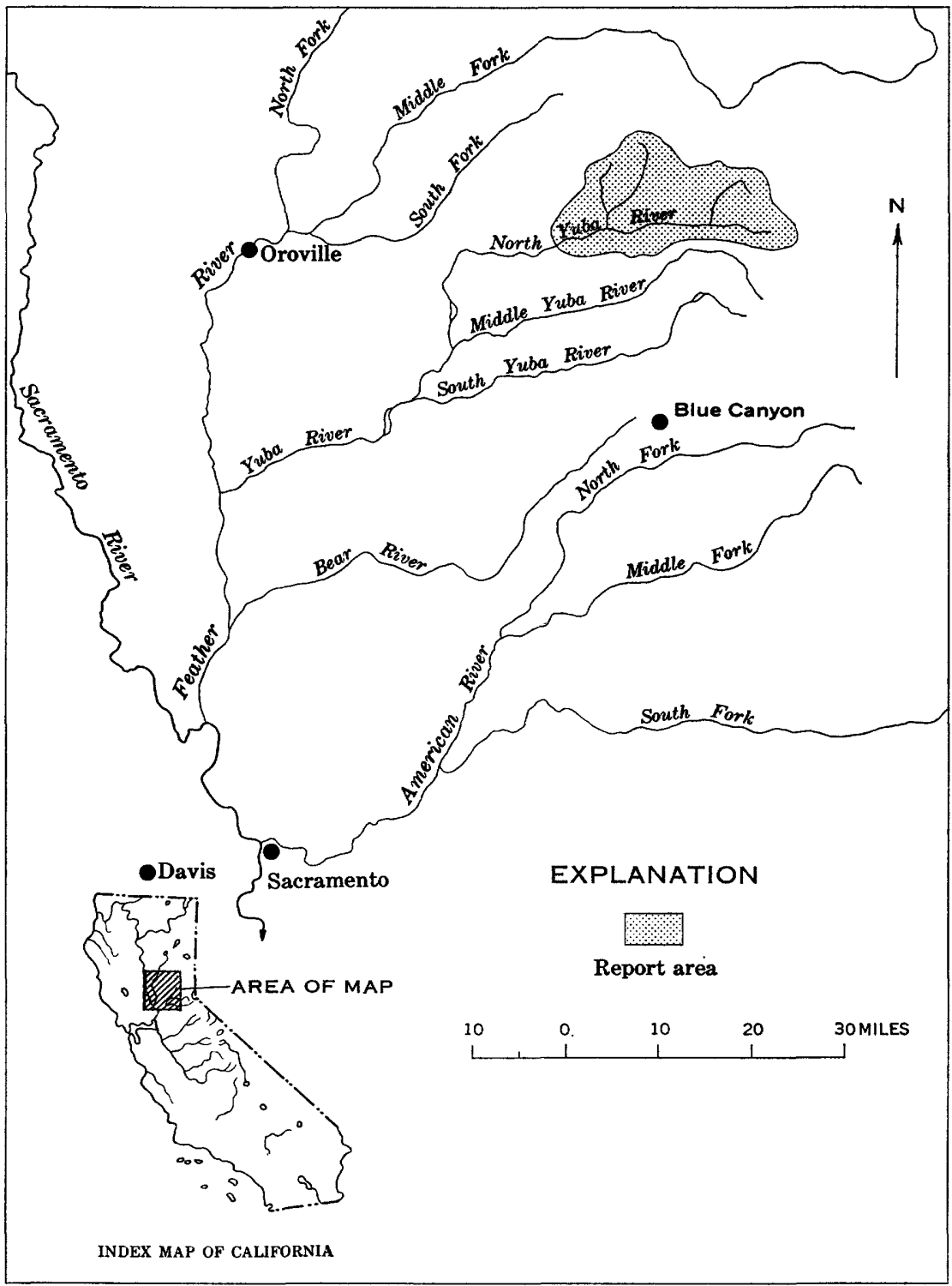

FIGURE 1.-Location map showing report area.

\section{ACKNOWLEDGMENTS}

The study described in this report was authorized by a cooperative agreement between the U.S. Geological Survey and the California Department of Water Resources. The report was prepared under the supervision of Walter Hofmann, district engineer of the Surface Water Branch of the Geological Survey. 
The cooperation of the U.S. Weather Bureau in furnishing unpublished meteorological data for the station at Blue Canyon, Calif., is gratefully acknowledged.

\section{THEORY OF SNOWMELT SNOWMELT AT A POINT}

This paper does not contain a detailed treatise on the theory of point and basin snowmelt. An excellent treatment of the subject is found in a summary report of the cooperative snow investigations by the U.S. Army Corps of Engineers (1956) and in a condensed version of that report by the same agency (1960). The paragraphs that follow have been largely abstracted from these publications to provide the modicum of theoretical background material that is needed for an understanding of the computational procedures used in this study of the North Yuba River basin.

Sources of heat.-The sources of heat involved in the melting of snow are:

1. Absorbed solar radiation, $H_{r s}$.

2. Net longwave (terrestrial) radiation, $H_{r l}$.

3. Convection heat transfer from the air, $H_{c}$.

4. Latent heat of vaporation by condensation from the air, $H_{e}$.

5. Conduction of heat from the ground, $H_{g}$.

6. Heat content of rainwater, $H_{p}$.

The summation of the net exchange from all sources of heat represents the amount of energy available for melting the snowpack, and the resulting melt may be expressed by the general formula

$$
M=\frac{\Sigma H}{203 B}
$$

where

$M=$ snowmelt in inches of water

$\Sigma H=$ algebraic sum of all heat components, in calories per square centimeter

$B=$ thermal quality (see below)

$203=$ number of calories per square centimeter required to melt 1 inch of water equivalent of ice at $0^{\circ} \mathrm{C}(80 \mathrm{cal}$ per gm $\times 2.54 \mathrm{~cm}$ per in).

Thermal quality.-A melting snowpack consists of a mixture of ice and a small quantity of free water. The term "thermal quality" denotes the ratio, by weight, of ice to the total snow mixture. For a melting mountain snowpack, after free drainage of water by gravity, the thermal quality normally ranges from 0.95 to 0.97 , corresponding 
to a retention of 3 to 5 percent liquid water. In equation 1 above, a value of 0.97 is usually used for $B$, the thermal quality.

Solar radiation.- The amount of heat transferred to the snowpack by solar (shortwave) radiation varies with latitude, season, time of day, atmospheric conditions, forest cover, and albedo (reflectivity) of the snow. Figure 2 shows the daily solar radiation on cloudless

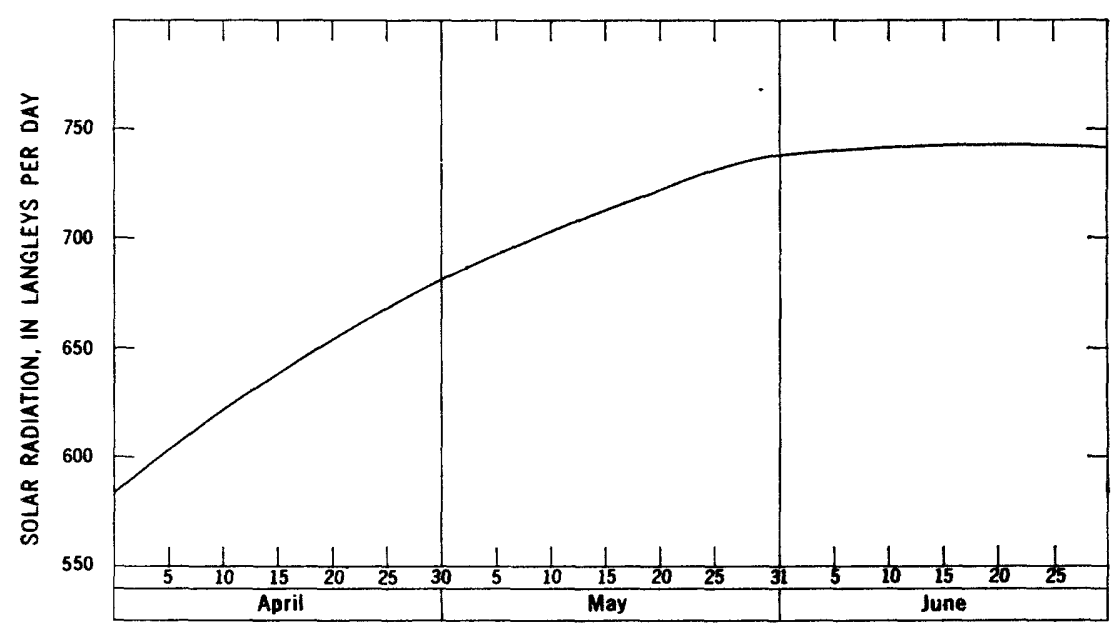

FIGURE 2.-Maximum daily solar radiation at latitude of North Yuba River basin. Curve interpolated from Hamon and others (1954, fig. 5).

days that is incident upon a horizontal surface at the latitude $\left(39^{\circ}\right.$ $35^{\prime}$ ) of the North Yuba River basin, during the 3-month snowmelt period, April through June.

Albedo.-The albedo, or reflectivity, of the snowpack varies over a considerable range, and greatly affects the amount of solar radiation absorbed by the pack. Albedo is expressed as the ratio of reflected shortwave radiation to that incident on the snow surface. Values range from more than 0.80 for new-fallen snow to as little as 0.40 for melting late-season snow. The melt equivalent from shortwave radiation, $M_{r s}$, in inches per day is

$$
M_{r s}=\frac{(1-a) I_{i}}{203 B}=0.00508 I_{i}(1-a)
$$

where

$a=$ albedo

$I_{i}=$ daily incident solar radiation in langleys

$B=$ thermal quality, assumed to be 0.97 . 
Longwave radiation.- - Snow is very nearly a black body with respect to longwave (terrestrial) radiation, absorbing almost all such radiation incident upon it, and emitting almost the maximum possible radiation corresponding to its temperature. A melting snowpack has a surface temperature of $0^{\circ} \mathrm{C}$, and, according to Stefan's law, loses energy at a rate of 0.459 langleys per minute. Opposed to this loss is the back radiation from the atmosphere or forest. For clear skies, the heat gain from back radiation is generally less than the heat loss, so that there is a net heat loss from the snowpack by longwave radiation. With cloudy skies or beneath a forest canopy, however, the back radiation may be greater or less than the loss from the snowpack, depending principally upon the ambient air temperature. Precise computation of back radiation from the atmosphere with clear skies is complex and far too cumbersome for practical use in snow hydrology. By applying some simplifying assumptions, however, the following simple equations are obtained for the melt equivalent from longwave radiation, $M_{r l}$, in inches per day. In the open with clear skies

$$
M_{r l}=0.0212\left(T_{a}-32\right)-0.84
$$

under forest canopy

$$
M_{r l}=0.029\left(T_{a}-32\right) .
$$

In equations 3 and 4

$T_{a}=$ the air temperature over the snow surface at the 10-foot level in degrees Fahrenheit.

Energy exchange from the atmosphere.-Turbulent heat exchange from the atmosphere involves the transfer of sensible heat from warm air advected over the snowfield (convection), and also the heat of condensation of atmospheric water vapor that is condensed on the snow surfaces (condensation). The principal elements affecting convective heat exchange are the temperature gradient of the atmosphere measured above the snow surface, and the corresponding wind speed. A secondary factor is the density of the atmosphere, which may be expressed as a function of air pressure. The prime factors affecting condensation melt are the vapor pressure gradient and the wind speed. The computation of heat exchange from the atmosphere is complex from a theoretical standpoint, and exchange coefficients are derived empirically from controlled experiments. By making some simplifying assumptions concerning air density ratios and the relation of dewpoint temperatures to vapor pressures, simple equations are obtained for $M_{c}$, the daily melt equivalent from convection, and $M_{e}$, the daily melt equivalent from condensation. Because similar terms appear in both equations, these equations may be combined into a 
single equation for the melt equivalent from convection and condensation, $M_{c e}$, in inches per day.

$$
M_{c e}=0.0084 v\left[0.22\left(T_{a}-32\right)+0.78\left(T_{d}-32\right)\right]
$$

where

$T_{a}=$ mean air temperature at the 10-foot level in degrees Fahrenheit

$T_{a}=$ mean dewpoint temperature at the 10-foot level in degrees Fahrenheit

$v=$ mean wind speed at the 50 -foot level in miles per hour.

Conduction of heat from the ground.- The heat conducted from the ground is almost negligible, and the complex observations required for its determination are therefore not warranted. The snowmelt from ground heat may be assumed to be 0.02 inch per day.

Heat content of rainwater. - Snowmelt resulting from the transfer of heat from rainwater is relatively small, and may be expressed simply in terms of amount of rainfall and dewpoint temperature. Dewpoint temperature is used because numerous investigators have demonstrated that this temperature closely approximates that of the raindrops. The melt equivalent from rainwater, $M_{p}$, in inches per day is

$$
M_{p}=0.007 \operatorname{Pr}\left(T_{d}-32\right)
$$

where

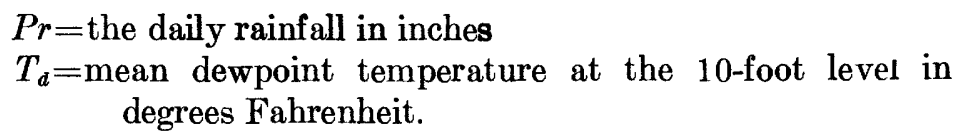

\section{BASIN SNOWMELT}

The snowmelt equations in the preceding section dealt with the evaluation of snowmelt at a point. To apply these equations to a mountainous basin, however, it is necessary to use coefficients for the effect of such local environmental features as forest cover and basin exposure. The density of the forest canopy is particularly important because it influences all the principal melt processes. For the purpose of deriving appropriate basin snowmelt coefficients for forested regions, the average forest density, $F$, in a basin was classified as shown below.

1. Open

2. Partly forested ${ }^{1} \ldots$

3. Heavily forested 
The second environmental feature, basin exposure, influences the amount of solar radiation the basin receives. Basins whose exposure is predominantly south-facing receive more insolation than do those that face the north. In recognition of this effect a basin shortwave radiation melt coefficient, $k^{\prime}$, was introduced. The value of $k^{\prime}$ is 1.0 for a basin that is largely horizontal or whose north and south slopes are equal in area. During the spring snowmelt season, the value of $k^{\prime}$ falls to 0.9 for a basin that is predominantly north-facing, and to 1.1 for a basin that is predominantly south-facing.

As for the effects of weather conditions on basin snowmelt, they are more easily discussed if rain periods are treated separately from rainfree periods.

Basin snowmelt during periods of rainfall.-The evaluation of basin snowmelt during periods of rainfall presents a special condition for which certain simplifying assumptions can be made in the snowmelt equations. During rainstorms, solar radiation melt is relatively small, and snowmelt resulting from longwave radiation is easily evaluated from theoretical considerations. Heat transfer by convection and condensation represents the major source of energy for snowmelt, but the equation for this transfer must be modified for the effect of the forest density of the basin. Evaluation of the various sources of heat transfer to the snowpack during periods of rainfall involves the basic considerations that follow.

1. Shortwave radiation is relatively unimportant. It can be expressed by the equation

where

$$
M_{r s}=(1-F)(0.07)
$$

$M_{r s}=$ solar radiation melt in inches per day

$F=$ forest density expressed as a decimal ratio

$0.07=$ the assumed daily radiation melt in the open.

2. Longwave radiation exchange between forest or low clouds and the snowpack may be computed as a linear function of air temperature.

where

$$
M_{r l}=0.029\left(\mathrm{~T}_{a}-32\right)
$$

$\mathrm{M}_{r l}=$ longwave radiation melt in inches per day $T_{a}=$ the mean air temperature at the 10 -foot level, in degrees Fahrenheit.

3. Air is assumed to be saturated, so that an air temperature-wind speed expression may be used in evaluating both convection and 
condensation melt. This is done by assuming a linear relation between vapor pressure and dewpoint. For computing convection-condensation melt on basins, it is necessary to introduce a basin constant, $k$, which represents the effect of forest density on the wind speed. The value of $k$ may be computed from the strictly empirical equation

where

$$
k=1-0.7 F
$$

$F=$ forest density expressed as a decimal ratio.

For open or partly forested areas, convection-condensation melt may be computed from the equation

$$
M_{c e}=k(0.0084 v)\left(T_{a}-32\right)
$$

For heavily forested areas, an average wind condition is assumed, thereby eliminating the wind variable, and the equation used is

$$
M_{c e}=0.045\left(T_{a}-32\right)
$$

In equations 10 and 11

$M_{c e}=$ convection-condensation melt in inches per day

$k=$ the basin constant described above

$v=$ mean wind speed at the 50 foot-level in miles per hour

$T_{a}=$ mean temperature of saturated air at the 10 -foot level in degrees Fahrenheit.

4. Rain melt (snowmelt from transfer of heat from rainwater) is expressed as a function of daily rainfall and dewpoint temperature. Under the assumption, however, of saturated air, the mean dewpoint temperature and mean air temperature will be identical. The equation for rain melt is

$$
M_{p}=0.007 \operatorname{Pr}\left(T_{a}-32\right)
$$

where

$M_{p}=$ rain melt in inches per day

$P r=$ daily rainfall in inches

$T_{a}=$ mean temperature of saturated air at the 10 -foot level, in degrees Fahrenheit. 
5. Ground melt (snowmelt from ground heat) is assumed to be constant at 0.02 inch per day.

Basin snowmelt during rain-free periods.-Rational determination of basin snowmelt during rain-free periods requires formulas that are more complex than those needed for periods of rainfall. Solar and terrestrial radiation both become important variables in the balance of heat exchange to the snowpack, and require direct evaluation for the given conditions of forest cover. Convection and condensation are generally less important heat sources than radiation. To arrive at generalized and simplified basin snowmelt equations for rain-free periods, the rational analysis of snowmelt at a point has been combined with statistically derived weightings of the air and dewpoint temperatures for varying conditions of forest environment.

Basic forms of the snowmelt equations, for the three classifications of forest density, involve the following considerations:

1. Open area (less than 10 percent cover)

a. Shortwave radiation is almost always the most important melt factor. Evaluation of this factor requires estimates of incident solar radiation, snow surface albedo, and the basin shortwave radiation melt coefficient.

b. Heat exchange by longwave radiation during cloud-free periods may be evaluated on the basis of surface air temperatures. Net longwave radiation exchange during periods of cloud cover may be estimated on the basis of cloud temperature and degree of cloud cover.

c. Convection and condensation snowmelt during clear weather is usually of minor importance. It may be evaluated with an air temperature, dewpoint temperature, and wind function, as previously discussed.

2. Partly forested area (10-80 percent cover)

a. Shortwave radiation melt is evaluated for the unforested parts of the basin, considering incident solar radiation, snow surface albedo, and the basin shortwave radiation melt coefficient.

b. Longwave radiation melt for the forested part of the basin may be evaluated linearly as an air temperature function. For the unforested part, heat loss by longwave radiation may be accounted for indirectly by reducing the shortwave radiation melt coefficient, thereby allowing longwave loss to be a function of net shortwave radiation.

c. A wind variable is specified for evaluation of convectioncondensation melt, together with a basin convectioncondensation melt coefficient.

3. Heavily forested area (more than 80 percent cover)

a. Shortwave radiation melt is a very minor element. 
b. Longwave radiation and convection melt may be combined into a single linear function of air temperature.

c. Wind is unimportant in evaluating convection and condensation melt.

d. Condensation melt may be evaluated as a linear function of dewpoint temperature.

\section{GENERALIZED BASIN SNOWMELT EQUATIONS}

Generalized basin snowmelt equations for direct use in solving problems in snow hydrology have been developed on the basis of the theoretical considerations and assumptions discussed in the preceding section, "Basin Snowmelt." These equations, which combine all components of melt, are applicable only for a snowpack that is isothermal at $32^{\circ} \mathrm{F}$ and contains 3 percent of free water.

General equations for basin melt during periods of rainfall

1. For open or partly forested areas

$$
\begin{gathered}
M=(0.029+0.0084 k v+0.007 \operatorname{Pr})\left(T_{a}^{\prime}\right) \\
+(1-F)(0.07)+0.02
\end{gathered}
$$

2. For heavily forested areas

$$
M=(0.074+0.007 \mathrm{Pr})\left(T_{a}^{\prime}\right)+(1-F)(0.07)+0.02
$$

General equations for basin melt during rain-free periods

1. For open areas

$$
\begin{aligned}
M= & k^{\prime}\left(0.00508 I_{i}^{1}\right)(1-a)+(1-N)\left(0.0212 T_{a}^{\prime}-0.84\right) \\
& +N\left(0.029 T_{c}^{\prime}\right)+k(0.0084 v)\left(0.22 T_{a}^{\prime}+0.78 T_{d}^{\prime}\right)+0.02
\end{aligned}
$$

2. For partly forested areas

$$
\begin{gathered}
M=k^{\prime}(1-F)\left(0.0040 I_{i}\right)(1-a)+k(0.0084 v)\left(0.22 T_{a}^{\prime}+0.78 T_{d}^{\prime}\right) \\
+F\left(0.029 T_{a}^{\prime}\right)+0.02
\end{gathered}
$$

3. For heavily forested areas

$$
M=0.074\left(0.53 T_{a}^{\prime}+0.47 T_{d}^{\prime}\right)+0.06
$$

In equations $13-17$

$\mathrm{F}=$ the forest-canopy cover of the basin, effective in shading the area from solar radiation, expressed as a decimal ratio.

$I_{i}^{\prime}=$ the incident solar radiation in langleys per day

$M=$ the snowmelt rate in inches per day

$N=$ the cloud cover, expressed as a decimal ratio

$P r=$ the daily rainfall in inches 
$T_{a}^{\prime}=$ the difference between the mean air temperature at the 10 foot level and the snow-surface temperature $\left(32^{\circ} \mathrm{F}\right)$ in degrees Fahrenheit

$T_{a}^{\prime}=$ the difference between the mean dewpoint temperature at the 10-foot level and the snow-surface temperature $\left(32^{\circ} \mathrm{F}\right)$ in degrees Fahrenheit

$T_{c}^{i}=$ the difference between the cloud-base temperature and snow-surface temperature $\left(32^{\circ} \mathrm{F}\right)$ in degrees Fahrenheit. Cloud-base temperature is estimated from upper air temperatures or by lapse rates from a surface station, which preferably is on a snow-free site

$a=$ the average snow-surface albedo

$k=$ the basin convection-condensation melt factor (see equation

9)

$k^{\prime}=$ the basin shortwave radiation melt factor (ranges from 0.9 to 1.1 )

$v=$ mean wind speed at the 50-foot level, in miles per hour.

\section{HYDROLOGIC CHARACTERISTICS OF THE NORTH YUBA RIVER BASIN}

Before using the general snowmelt formulas for computing snowmelt runoff of the North Yuba River basin, it was first necessary to evaluate pertinent basin characteristics. The study area, which is located in the Sierra Nevada, is 245 square miles in area and is drained by the headwaters of the North Yuba River and its principal tributary, Downie River (fig. 3). Altitudes in the watershed range from 2,450 feet at the gaging station below Goodyears Bar to 8,590 feet at Lookout Peak, 2 miles north of Sierra City. Figure 4 is a hypsometric curve for the North Yuba River basin showing the area-altitude distribution. The area lying within various altitude zones and the forest density for these zones were determined from the latest Geological Survey maps and are listed in table 1. The forest density figures, though crudely derived, compare favorably with those obtained by the U.S. Forest Service in an inventory of forests and large brushfields in the Sierra Nevada (Anderson and Richards, 1961, p. 145). The Forest Service report shows a cover of 61 percent for all the Yuba River basin above 5,000 feet; table 1 indicates a forest density of 65 percent for that part of the North Yuba River basin above 5,000 feet.

The altitude of the snowline at the beginning of the snowmelt season (approx. Apr. 1) varies annually and averages about 4,500 feet. Average annual precipitation over the entire basin is approximately 60 inches; the annual average water equivalent of the basin snowpack on April 1, over the 80 percent of the basin that is normally snow covered on that date, is about 24 inches. Table 2 presents 

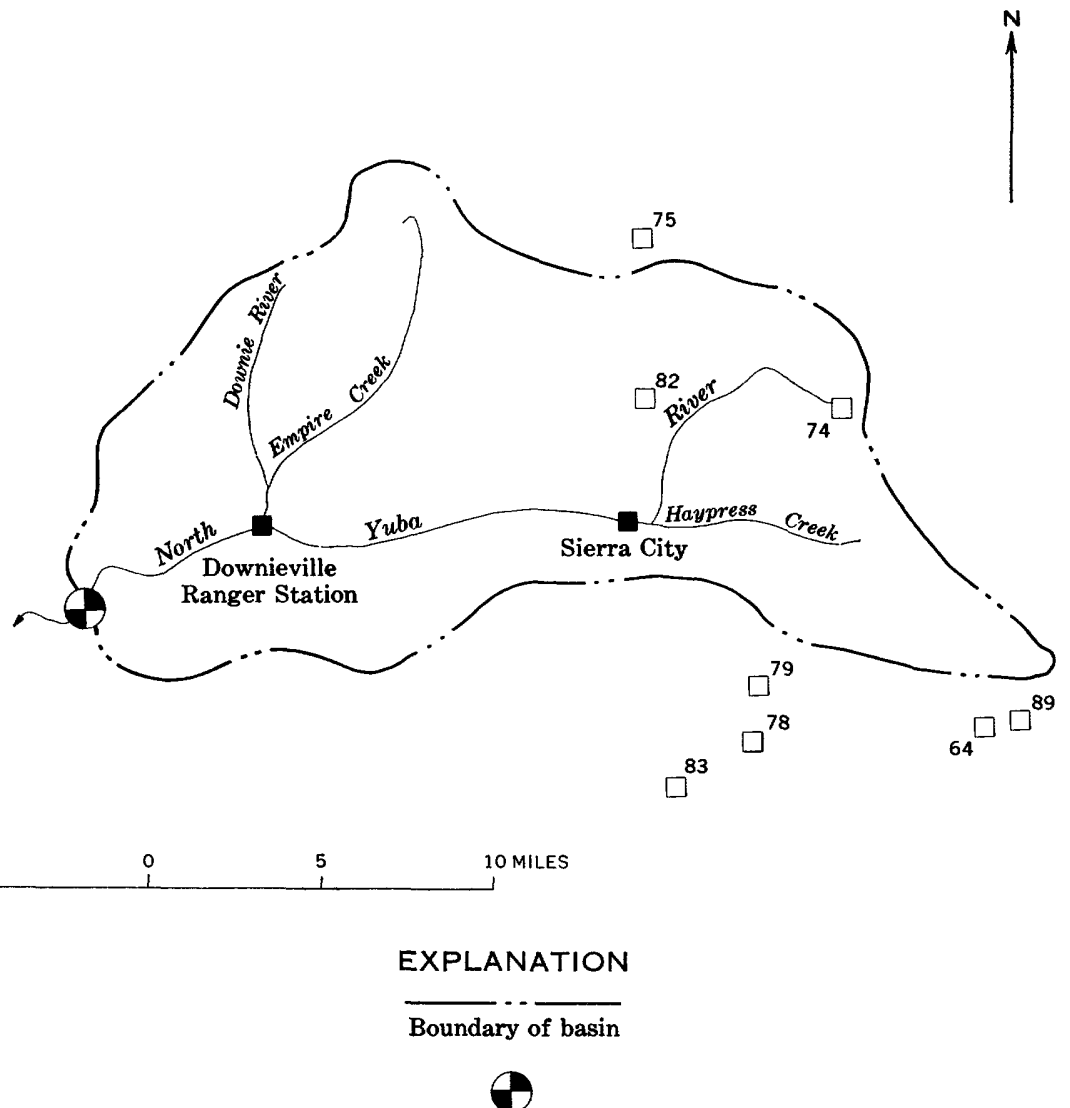

Stream-gaging station below Goodyears Bar

Weather Bureau station (precipitation and temperature)

$\square^{82}$

Snow course

FIGURE 3.-Sketch map of North Yuba River basin upstream from Goodyears Bar.

data for the eignt snow courses shown on figure 3 , for the 3 years $(1956,1958$, and 1959) that were used in this study. Measurements of water equivalent of the snowpack are normally made as close as possible to April 1 each year. In 1958, however, only two snow courses were observed in early April because of unseasonably heavy storms that occurred during the period March 29 to April 3. Data from table 2 were plotted in figure 5 to show the relation of water equivalent of snowpack to altitude. Snowpack data pertinent to this study were then extracted from figure 5 and entered in table 1. 
R14 CONTRIBUTIONS TO THE HYDROLOGY OF THE UNITED STATES

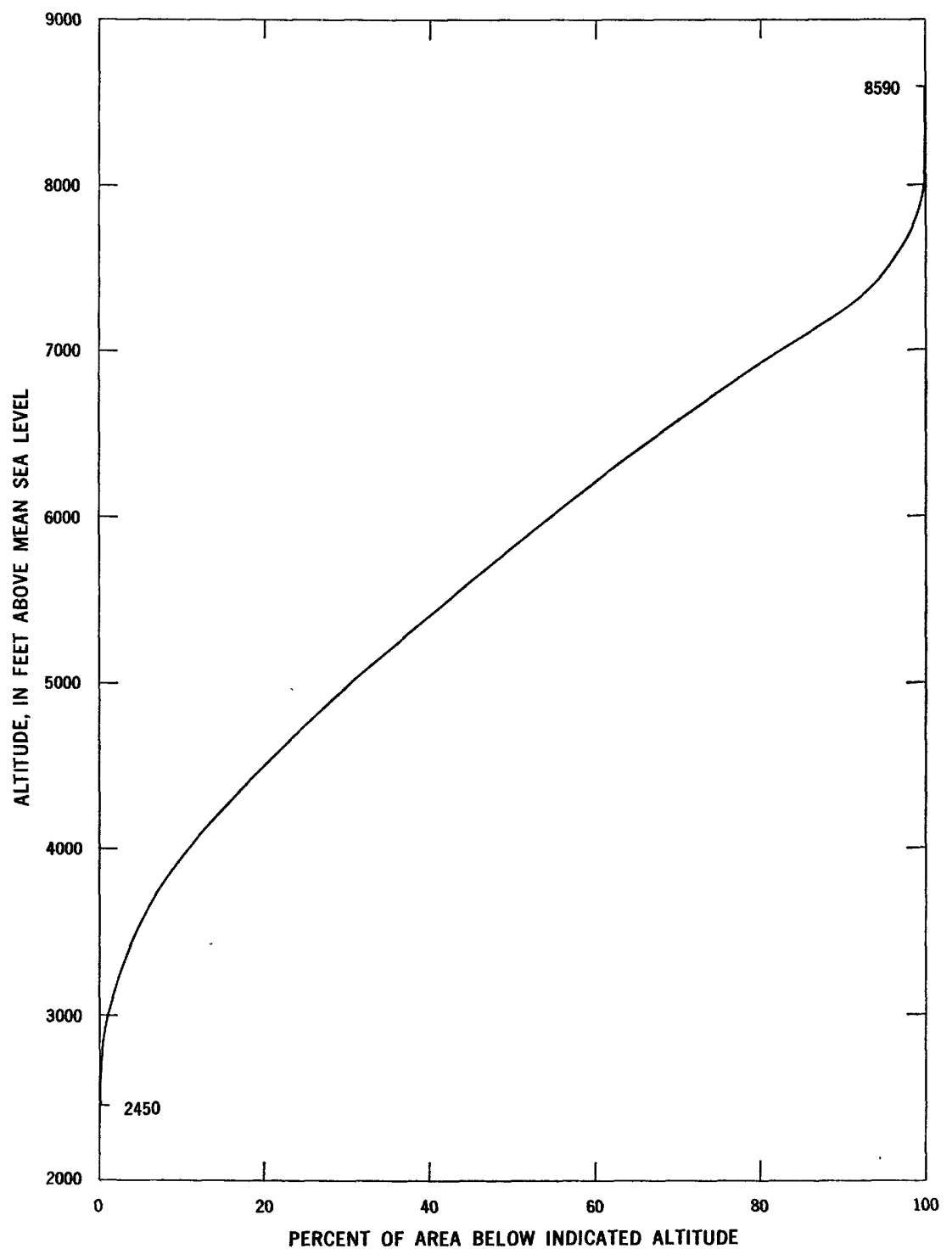

Figure 4.-Area-altitude distribution for the North Yuba River basin.

A preceding section of this report discussed the influence of basin exposure on the amount of solar radiation received, and introduced a basin shortwave radiation melt coefficient, $k^{\prime}$. Because the North Yuba River watershed is predominantly south-facing, the value of $k^{\prime}$ was assumed to be 1.1 . 
TABLE 1.-Hydrologic characteristics of the North Yuba River basin

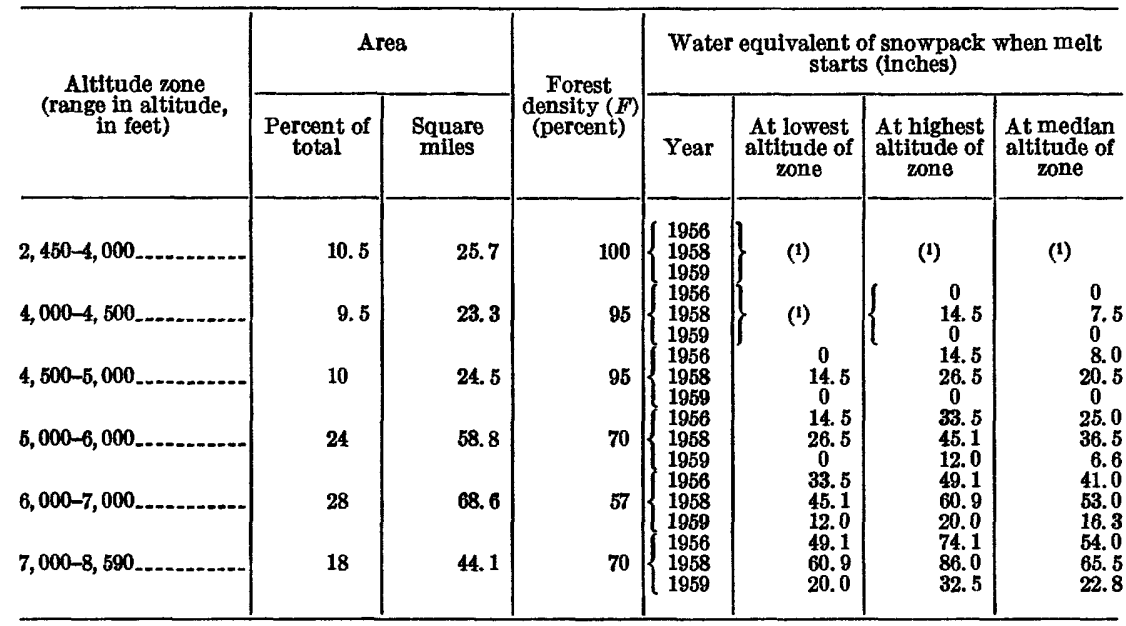

1 No snow.

TABLE 2.-Snow-course data for the North Yuba River basin

\begin{tabular}{|c|c|c|c|c|c|c|c|c|}
\hline & \multicolumn{8}{|c|}{ Data on water equivalence for indicated snow course } \\
\hline & 64 & 74 & 75 & 78 & 79 & 82 & 83 & 89 \\
\hline $\begin{array}{l}\text { Altitude } \\
\text { 30-year average water } \\
\text { equivalent on April } \\
\text { 1. }\end{array}$ & $\begin{array}{r}7,800 \\
42.0\end{array}$ & 6,700 & 6,700 & $\begin{array}{r}6,500 \\
27.6\end{array}$ & $\begin{array}{r}6,300 \\
29.1\end{array}$ & $\begin{array}{r}5,700 \\
18.0\end{array}$ & $\begin{array}{r}5,650 \\
19.9\end{array}$ & $\begin{array}{r}6,800 \\
30.9\end{array}$ \\
\hline 1956: & Mar. 26 & Mar. 29 & Mar. 30 & Mar. 28 & Mar. 28 & Apr. 2 & Mar. 28 & Mar. 26 \\
\hline $\begin{array}{l}\text { water equivg- } \\
\text { lent....inches.. }\end{array}$ & 64.2 & 48.2 & 42.8 & 39.5 & 42.0 & 20.4 & 28.1 & 46.0 \\
\hline $\begin{array}{l}\text { Date.... } \\
\text { Water equiva } \\
\text { lent }\end{array}$ & $\begin{array}{r}1 \text { Apr. } 22 \\
70.1\end{array}$ & $\begin{array}{r}2 \text { Mar. } 31 \\
44.5\end{array}$ & $\begin{array}{r}\text { Apr. } 3 \\
56.3\end{array}$ & $\begin{array}{r}1 \text { Apr. } 23 \\
50.0\end{array}$ & $\begin{array}{r}1 \text { Apr. } 23 \\
50.8\end{array}$ & $\begin{array}{r}\text { Apr. } 7 \\
40.7\end{array}$ & $\begin{array}{r}1 \text { Apr. } 23 \\
42.0\end{array}$ & $\begin{array}{r}1 \text { Apr. } 22 \\
48.4\end{array}$ \\
\hline $\begin{array}{l}\text { 1959: } \\
\text { Date...... } \\
\text { Water equiva } \\
\text { lent... inches. }\end{array}$ & $\begin{array}{r}\text { Mar. } 31 \\
26.2\end{array}$ & $\begin{array}{r}\text { Mar. } 30 \\
16.7\end{array}$ & $\begin{array}{r}\text { Mar. } 31 \\
20.0\end{array}$ & $\begin{array}{r}\text { Apr. } 1 \\
13.8\end{array}$ & $\begin{array}{r}\text { Apr. } 1 \\
18.3\end{array}$ & $\begin{array}{r}\text { Mar. } 31 \\
9.6\end{array}$ & $\begin{array}{r}\text { Apr. } 1 \\
9.1\end{array}$ & $\begin{array}{r}\text { Mar. } 31 \\
18.7\end{array}$ \\
\hline
\end{tabular}

1 After snowmelt had progressed.

2 Prior to heavy storm of early April.

\section{ANALYSIS OF SNOWMELT RUNOFF}

\section{S YNTHESIS OF HYDROMETEOROLOGICAL ELEMENTS}

Few basins can be found where all the hydrometeorological elements required for computing snowmelt are observed. The North Yuba River basin is not such a basin. The only meteorological stations there are at Sierra City (alt 4,182 ft) and Downieville Ranger Station (alt 2,895 ft), and at these stations only precipitation and temperature are observed (fig. 3). It was therefore necessary to derive synthetic daily values of the many elements required in the generalized basin snowmelt equations. 


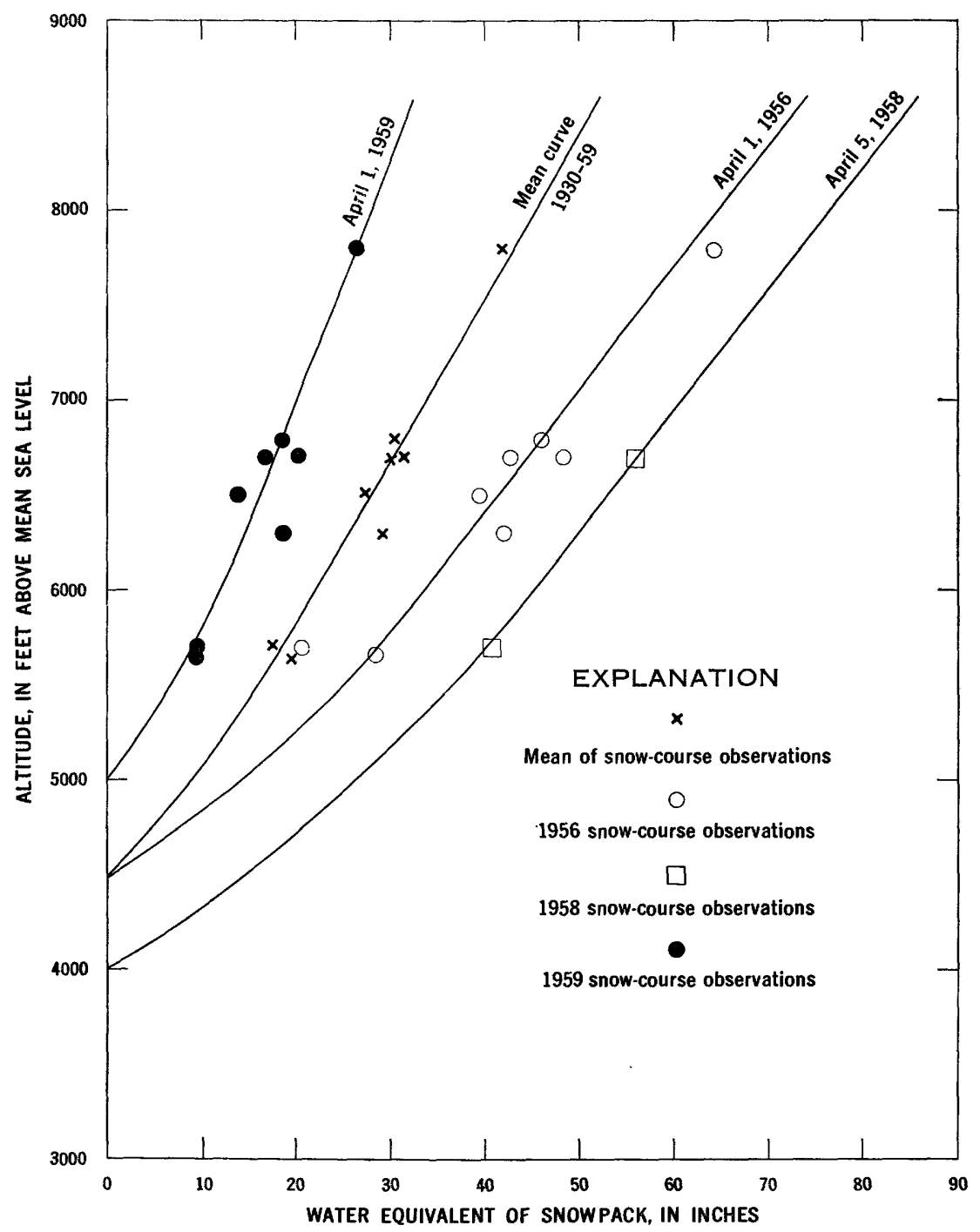

FiguRE 5.-Relation of water equivalent of snowpack to altitude, at start of melt season.

Weather records for Sierra City were incomplete for the period studied; consequently, the observations recorded at Downieville Ranger Station were used to derive figures of air temperature and precipitation for each of the altitude zones listed in table 1 . The daily mean temperature at the station was computed by the accepted method of averaging the maximum and minimum temperatures recorded each day. To obtain the daily mean temperatures for each altitude zone, a lapse rate of $3^{\circ} \mathrm{F}$ per 1,000 feet of altitude was 
applied to the Downieville temperatures. This lapse rate, computed from temperature records at nearby stations, is in agreement with the figure commonly used in studies in the Sierra Nevada.

The precipitation that occurred in each altitude zone during the snowmelt season was assumed to be equivalent to that recorded at Downieville Ranger Station. This assumption does not lead to serious error because the mean annual precipitation at the meteorological station agrees very closely with the mean annual basinwide precipitation. When air temperatures were close to $32^{\circ} \mathrm{F}$, there was some question as to whether the precipitation was in the form of rain or snow. This was resolved by the use, at such times, of the snowfall record for the meteorological station at Blue Canyon (fig. 1) at altitude 5,280 feet.

The daily mean dewpoint temperature for each altitude zone was based on the record of observed dewpoints at Blue Canyon. During fair weather, a dewpoint lapse rate of $1^{\circ} \mathrm{F}$ per 1,000 feet of altitude was assumed; during periods of precipitation the pseudoadiabatic lapse rate of $3^{\circ} \mathrm{F}$ per 1,000 feet of altitude was used. It was found that during periods of precipitation a difference of a few degrees generally existed between the air temperature and the dewpoint temperature. For those occasions, equations 13 and 14 were modified by substituting $\left[\frac{\left(T_{a}^{\prime}+T_{d}^{\prime}\right)}{2}\right]$ for $T_{a}^{\prime}$. Because none of the altitude zones in the basin was classed as open terrain, equation 15 was not used in this study, and accordingly there was no need to estimate $T_{c}^{\prime}$, the difference between cloud-base temperature and snow-surface temperature.

In synthesizing a daily record of incident solar radiation for the North Yuba River basin, it was necessary to use the records of daily insolation and cloud cover for Davis (fig. 1), together with the observations of cloud cover at Blue Canyon. As a first step, the solar radiation observed each day at Davis was expressed as a percentage of the maximum daily radiation that could be received on that date at the latitude of Davis $\left(38^{\circ} 32^{\prime}\right)$. This percentage was plotted on figure 6 against the corresponding cloud cover at Davis. The relation curve obtained was assumed to be as valid for the Sierra Nevada as it was for the Sacramento Valley, where Davis is located. The values of cloud cover observed at Blue Canyon were then used with the curve in figure 6 to obtain the percent of maximum daily insolation in the North Yuba River basin. These daily percentages were finally applied to the maximum solar radiation data for the North Yuba River basin, shown on figure 2, to give daily values of incident solar radiation in the study area. These daily figures of incident insolation were applicable to all altitude zones in the basin. 


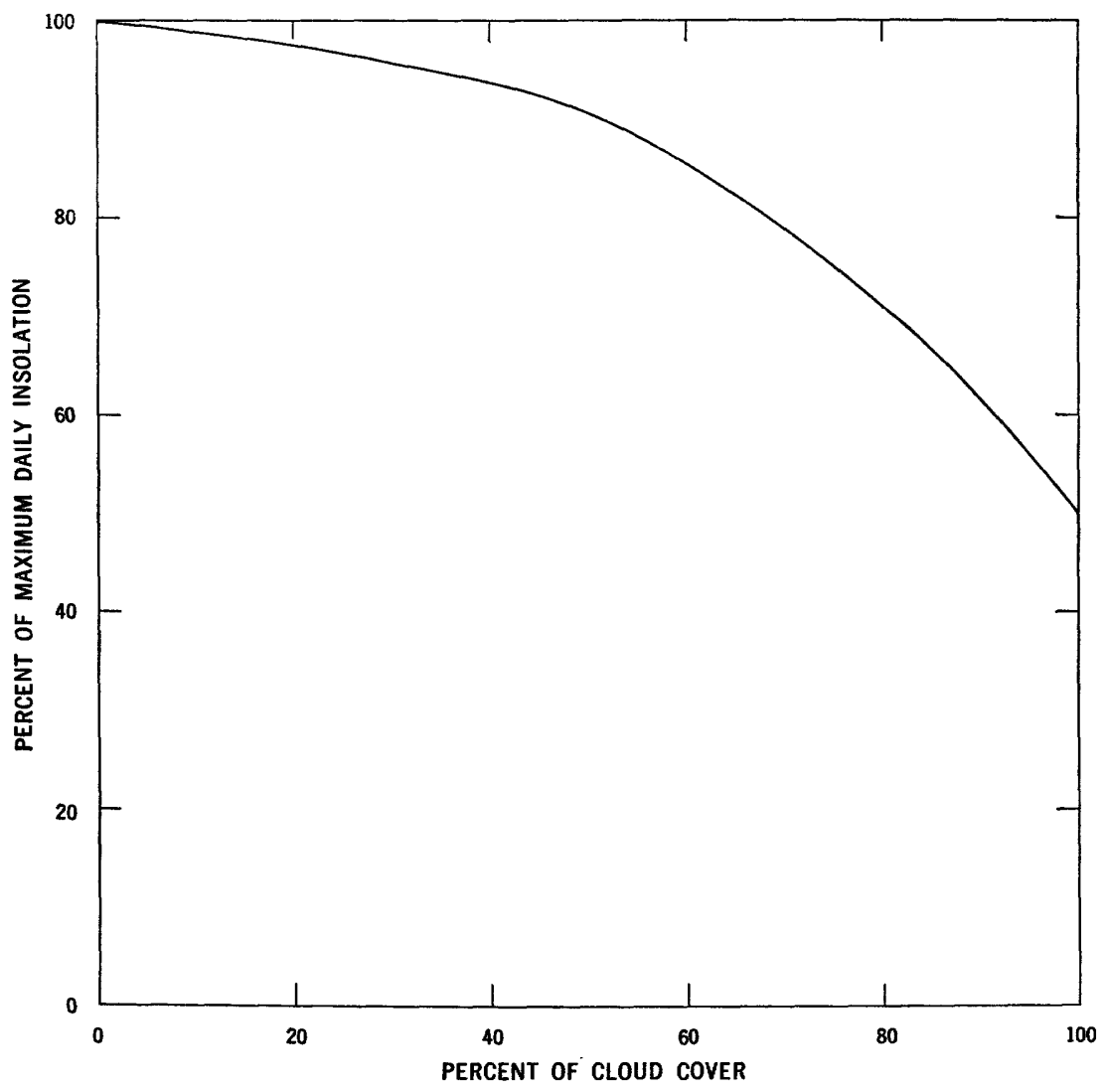

FigURE 6.-Relation between cloud cover and percent of maximum daily insolation at Davis, Calif, for period April 1 through June 30.

The relation shown in figure 6 is approximate. The individual points that defined the relation were widely scattered and are not shown in the figure. This scatter is understandable in view of the fact that the solar radiation incident at the ground surface is affected not only by the percentage of cloud cover, but also by thickness of the clouds and their location in the sky relative to the position of the sun. It would have been much more desirable to use duration of sunshine as an index of incident radiation (Hamon and others, 1954) rather than cloud cover, but, unfortunately, this element is not observed at any nearby Sierra Nevada meteorological stations.

Because only part of the incident solar radiation is absorbed by the snowpack, a daily record of the albedo of the snow surface was needed. Nowhere is this element regularly observed, but it may be estimated from relations that were derived at the mountain laboratory basins. At best such estimates must be considered only approximations, but 
limiting conditions during the snowmelt season are fairly well known. Figure 7 shows a typical variation of snow-surface albedo with time during the snowmelt season, and this relation was used for all altitude zones. An albedo of 0.65 was assumed at the start of each snowmelt season and immediately following any snowfall during the season; the lower limit of the albedo was assumed to be 0.40. A value of 0.40 was used on days when rain fell during the melt season.

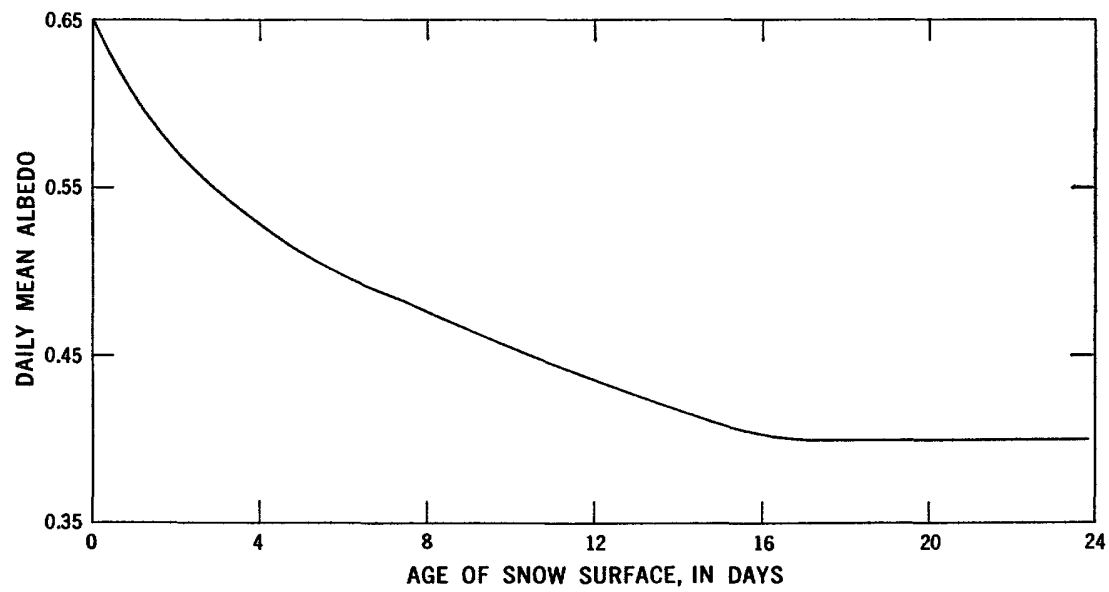

FiguRe 7.-Variation of snow-surface albedo with time during the snowmelt season.

The remaining meteorological element to be deduced was wind speed. The daily average wind speed observed at Blue Canyon was used directly for all altitude zones in the North Yuba River basin. Because wind speed is affected greatly by the local environment, it was not considered practicable to attempt any adjustments in transferring observed wind speeds from Blue Canyon to the study area.

\section{COMPUTATION OF DAILY SNOWMELT}

With a record, either synthetic or observed, of all the necessary hydrometeorological elements, the snowmelt in each altitude zone can be computed. The formulas in the preceding sections of this report are applicable only for a snowpack that is ready to produce runoff (one that is isothermal at $32^{\circ} \mathrm{F}$ and contrins 3 percent free water). Some criterion was therefore required to identify the date when the snowpack reached that condition. This date was arbitrarily assumed to be the first day, after the snow survey of late March or early April, when the recorded stage hydrograph for the river showed the easily identifiable diurnal fluctuation that is characteristic of snowmelt runoff. The closing date for the study in any year was the day when streamflow had receded to the discharge 
recorded on the opening date of the study and had entered the baseflow recession phase of the runoff cycle. For the years that were investigated, the study dates were as follows:

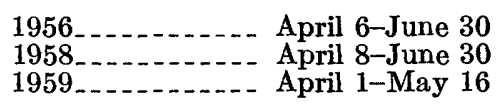

Snowmelt does not start simultaneously in all altitude zones. A certain amount of heat is required to ready the snowpack for runoff, and the colder upper altitude zones will lag behind the lower altitude zones in receiving the necessary heat. It was arbitrarily assumed that at the start of the snowmelt season each year, the snowpack in the altitude zone between 6,000 and 7,000 feet would have an average temperature of $-2^{\circ} \mathrm{C}$, and in the altitude zone between 7,000 and 8,590 feet, an average temperature of $-4^{\circ} \mathrm{C}$. (The centigrade scale was used in these assumptions to simplify the computations.) Consequently, no melt was assumed to occur in these upper altitude zones until sufficient heat had been transmitted to the snowpack to raise its temperature to $0^{\circ} \mathrm{C}$ and then melt 3 percent (by weight) of the pack. This heat deficit, $M_{d}$, expressed in equivalent inches of melt water, is computed from the formula

$$
M_{d}=\frac{W_{o} T}{160}+0.03\left[W_{o}+\frac{W_{o} T}{160}\right]
$$

where

$W_{o}=$ initial average water equivalent of the snowpack, in inches

$T=$ average snowpack temperature in ${ }^{\circ} \mathrm{C}$ below zero

$160=$ latent heat of fusion of ice ( $80 \mathrm{cal}$ per $\mathrm{gm})$ divided by specific heat of ice $\left(0.5 \mathrm{cal}\right.$ per gm per $\left.{ }^{\circ} \mathrm{C}\right)$

$0.03=3$ percent of free water.

The liquid water needed to overcome the heat deficit may be supplied by either snowmelt or rain.

If rain falls on a melting snowpack, the rainwater is transmitted without loss through the pack and is subject to only minor detention lag (U.S. Army Corps of Engineers, 1956, p. 304-308). Should snow be the form of precipitation, however, it is assumed that the only water made available for runoff will be that due to ground melt, 0.02 inch per day.

With these additional assumptions established, equations 9, 13, 14, 16,17 , and 18 were applied and the daily snowmelt component of runoff for each altitude zone was computed. However, as snowmelt progresses the snowline recedes, and the snow-covered part of the zone diminishes in area. Consequently it was necessary to establish a procedure for determining the effective area of snowmelt. In any 
zone, the entire area was assumed to be contributing snowmelt until the day when the accumulated melt exceeded the water equivalent at the lowest altitude of the zone. For example, consider the altitude zone between 5,000 and 6,000 feet in 1956. Table 1 shows that the water equivalent of the pack on April 1 of that year was 14.5 inches at altitude 5,000 feet and 33.5 inches at altitude 6,000 feet. By May 7, the melt in this zone totaled 14.5 inches, and by May 30 it totaled 33.5 inches. Consequently, it was assumed that: (1) until May 8 the entire zone was contributing melt, (2) after May 30 the entire zone was bare of snow, and (3) between May 9 and May 30 a steadily decreasing percentage of the area in the zone was snow covered.

The percentage of area that was snow covered, or effective, on any given date in mid-May was computed by the following procedure. Between May 8 and May 30 the snowmelt amounted to 19 inches (33.5 in. minus 14.5 in.). On May 8 the daily snowmelt was 0.45 inch. It was assumed therefore that on May 8 the snow-covered area shrank by a percentage equal to $0.45 / 19.00 \times 100$, or 2.4 percent. Consequently, on May 9, only 97.6 percent of the area in the zone was effective in contributing snowmelt. To compute effective area on some other date, May 20 for example, the melt between the inclusive dates of May 8 and May 19 was added. The sum equaled 7.40 inches and the assumption was made that on May 19 the snow-covered area had shrunk by a percentage equal to $7.40 / 19.00 \times 100$, or 39 percent. Therefore the effective area on May 20 was 61 percent of the total in the zone.

Finally, to obtain the water produced on each day in each zone, the computed snowmelt for the day was multiplied by the percentage of zonal area that was effective on that date, and to this product was added the rainfall, if any. It is of interest that the maximum snowmelt computed for any day during this study was 2 inches. The only large quantity of runoff that was produced by rain on the snowpack occurred on May 4, 1956, when the daily discharge was $3,400 \mathrm{cfs}$ (cubic feet per second). Eighty-five percent of the water available for runoff at that time was contributed by rainfall.

Having computed the daily increment of water, in inches, produced in each zone, and knowing the percentage of the total basin area occupied by each zone (table 1), it was simple to compute the daily equivalent depth of water produced over the entire basin. The weighting method of determining this equivalent depth is illustrated in the computation shown below for May 22, 1958. Figures in the last column are obtained by multiplying those in the two preceding columns. 


\begin{tabular}{|c|c|c|c|}
\hline \multirow{2}{*}{ Altitude zone (feet) } & \multirow{2}{*}{$\begin{array}{l}\text { Percent of } \\
\text { total area }\end{array}$} & \multicolumn{2}{|c|}{ Depth of water (inches) } \\
\hline & & Zone & $\underset{\text { equivalent }}{\text { Basin }}$ \\
\hline \multirow[t]{2}{*}{$\begin{array}{l}\mathbf{2}, 450-4,000 \\
4,000-5,000 \\
\mathbf{5}, 000-6,000 \\
7,000-7,000\end{array}$} & \multirow[t]{2}{*}{$\begin{array}{l}\text { 10. } 5 \\
\text { 19. } 5 \\
\text { 24. } 0 \\
28.0 \\
18.0\end{array}$} & \multirow[t]{2}{*}{$\begin{array}{rr}1 & 0.550 \\
1 & 1.550 \\
2 & 1.331 \\
2 & 1.546 \\
2 & 1.345\end{array}$} & $\begin{array}{r}0.058 \\
.107 \\
.319 \\
.433 \\
.242\end{array}$ \\
\hline & & & 1. 159 \\
\hline
\end{tabular}

1 Rain only.

2 Snowmelt and rain.

Daily figures of equivalent depth of water produced over the basin are listed in table 3 under the heading "Available Supply."

\section{COMPUTATION OF DAILY RUNOFF}

Daily runoff during the snowmelt season was computed by routing the melt and rainwater for each day to the gaging station below Goodyears Bar. There are many complicating faotors, however. Lag time increases as the season progresses because ablation of the snowpack increases the distance between the gaging station and the snowfield. Because the intensity of snowmelt generation is low, a large part of the melt infiltrates and reaches the ground-water body, and much of the surface runoff proceeds to the various watercourses as interflow. The basinwide value of infiltration itself is reduced during the season as snowpack area diminishes, but the reduction is not directly proportional to the change in snowpack area; some of the surface runoff traversing the areas from which all snow has been melted, undoubtedly infiltrates and reaches the ground-water body. Moisture content of soil probably decreases during the course of the season as a result of evaportranspiration, although interflow tends to maintain the content at high levels. Meanwhile, the rate of evapotranspiration loss increases as the melt season progresses and temperatures rise, but this increase in rate is offset, to a large degree, by the reduced availability of water as the snow-covered area shrinks.

Various assumptions concerning infiltration and evapotranspiration loss, that are consistent with the statements in the preceding paragraph, were tested. The criteria finally adopted for these two elements are listed in table 4.

The appropriate values of infiltration and evapotranspiration loss from table 4 were entered in table 3 . In the latter table the surfacerunoff increment is the difference between available supply and infiltration. On those days when infiltration exceeds available supply, the surface runoff is zero and the increment to ground water is the 
SNOWMELT HYDROLOGY OF A SIERRA NEVADA STREAM

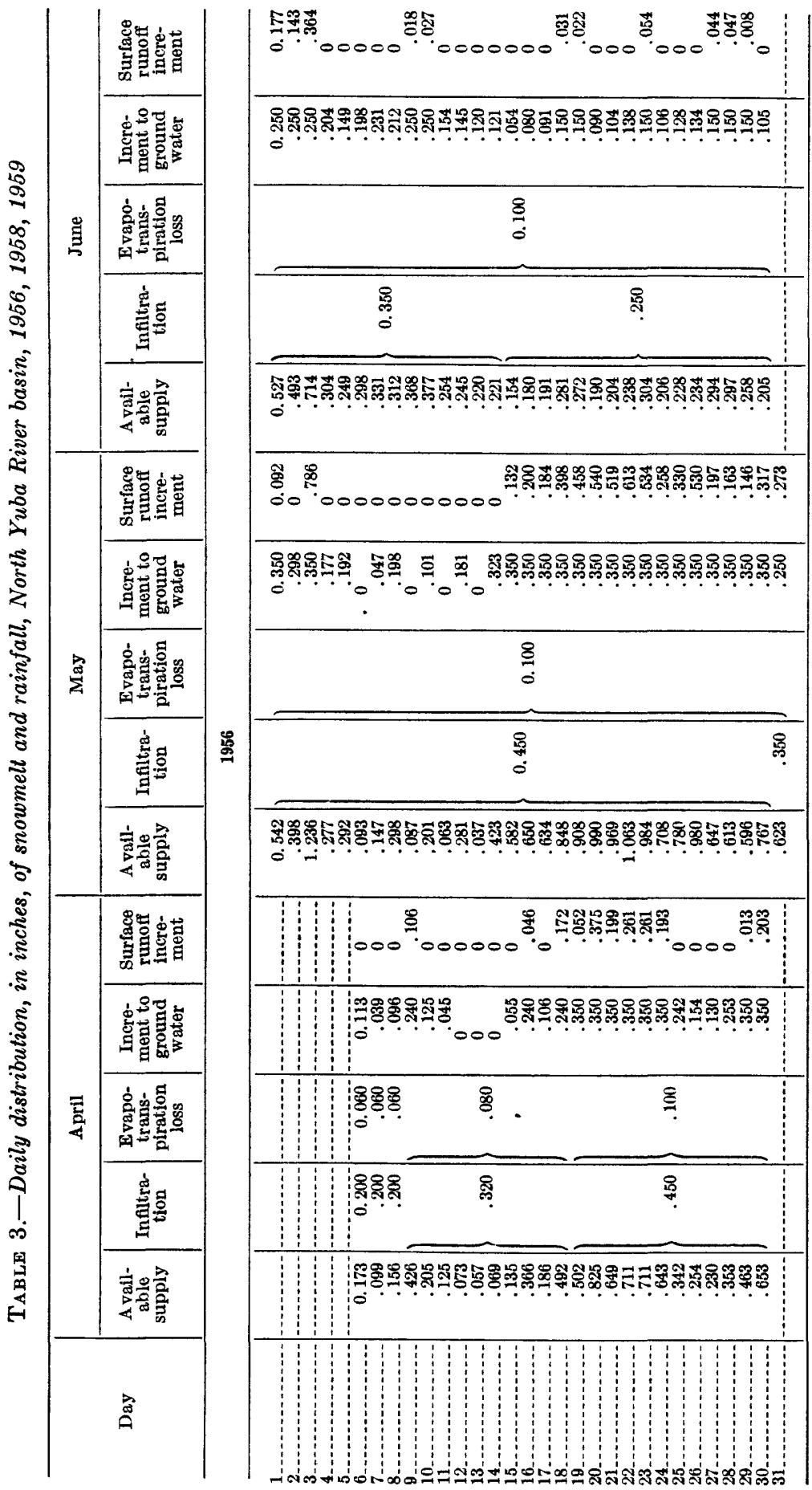


R24 CONTRIBUTIONS TO THE HYDROLOGY OF THE UNITED STATES

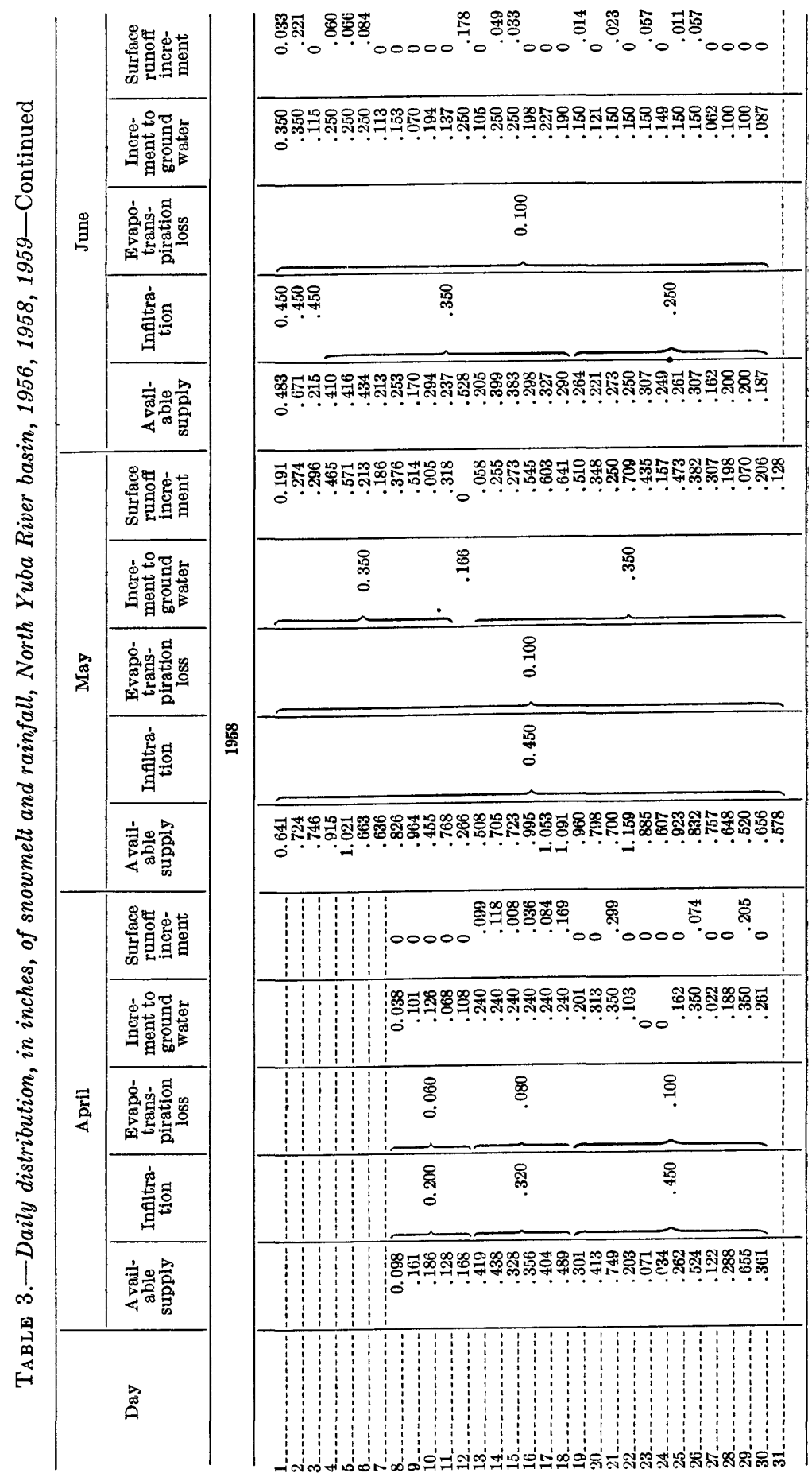




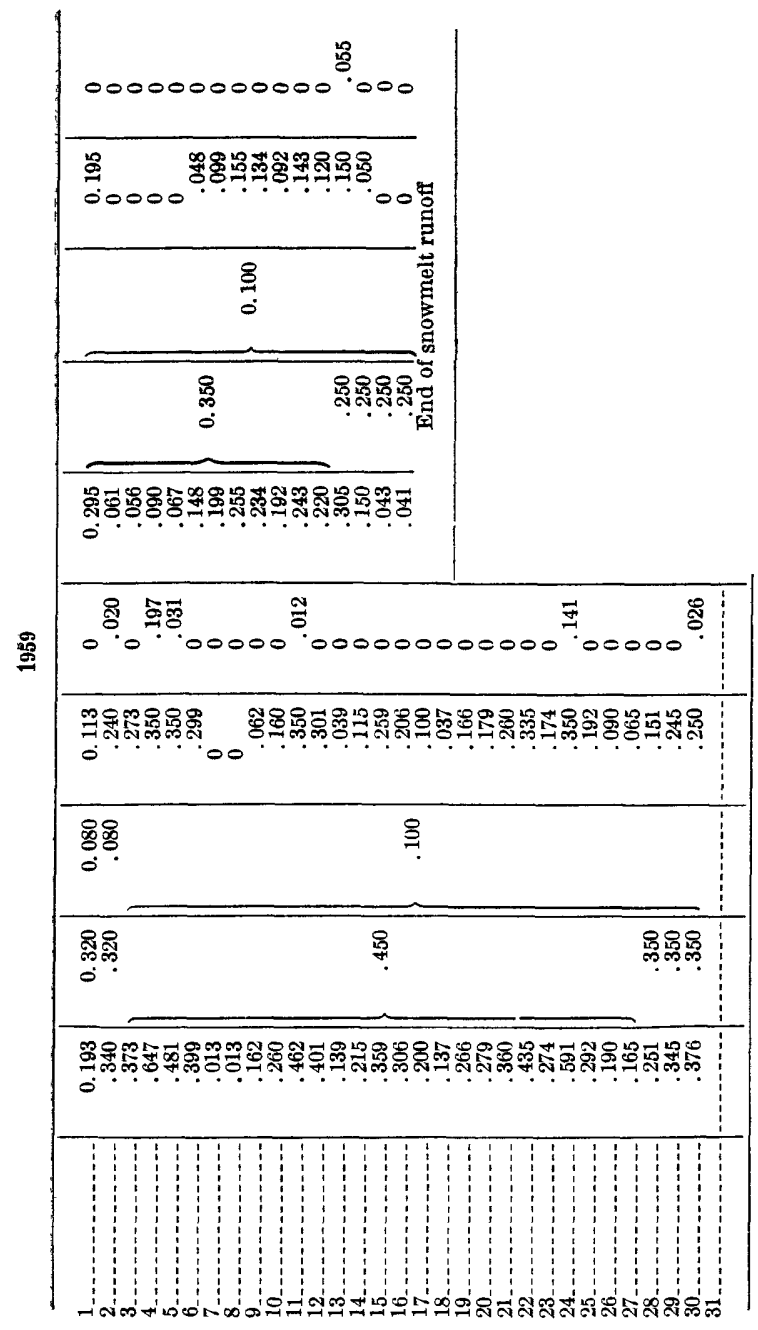


difference between available supply and evapotranspiration loss. On days when surface runoff occurs, the increment to ground water is the difference between infiltration and loss.

\section{TABLE 4.-Daily infiltration and evapotranspiration loss for various conditions of snow cover}

[Altitude zones: A, snow-covered area below 5,000 ft; $\mathrm{B}$, between 5,000 and $6,000 \mathrm{ft}$; C, between 6,000 and $7,000 \mathrm{ft} ; \mathrm{D}$, between 7,000 and $8,590 \mathrm{ft}]$

\begin{tabular}{|c|c|c|}
\hline $\begin{array}{c}\text { Altitude zones contributing } \\
\text { snowmelt }\end{array}$ & $\begin{array}{c}\text { Infiltration } \\
\text { (inches per day) }\end{array}$ & $\begin{array}{c}\text { Evapotranspiration } \\
\text { loss (inches per day) }\end{array}$ \\
\hline A, B 1 & 0.20 & 0.06 \\
B $^{1}$ & .20 & .06 \\
A, B, C & .32 & .08 \\
B, C & .32 & .08 \\
A, B, C, D & .45 & .10 \\
B, C, D & .45 & .10 \\
C, D & .35 & .10 \\
D & .25 & .10 \\
\hline
\end{tabular}

I In early April when heat deficit exists in zones $\mathrm{C}$ and $\mathrm{D}$.

2 In early April when heat deficit exists in zone $\mathrm{D}$.

The daily increment of supply that reaches the ground-water body affects the base flow of the North Yuba River in the same manner that inflow affects the outflow of a surface-water detention reservoir. When this increment of supply is greater than the base flow, both the base flow and the amount of ground water in storage are increased. Conversely, when the daily increment to ground water is less than the base flow, both the base flow and the ground-water storage are reduced. In accordance with the principle of conservation of mass, the daily change in storage, in each instance, is equal to the difference between the daily increment to ground water and the daily volume of base flow. A prerequisite then for routing the increment of supply through ground-water storage is the establishment of the relation between volume of ground-water storage and base flow.

To obtain this relation it was first necessary to derive the base-flow recession curve for the river at the Goodyears Bar gage site. This curve, shown in figure 8 , averages the discharge recessions recorded at the gaging station during the past several years. The area under the curve was computed using the base-flow discharge of $210 \mathrm{cfs}$ as an arbitrary lower limit (area $=0$ when base flow $=210 \mathrm{css}$ ). The area bounded by (1) the curve, (2) the number of days corresponding to the lower limit of $210 \mathrm{cfs}$, and (3) the number of days corresponding to some greater value of base flow, $X \mathrm{cfs}$, represents the volume of live ground-water storage (above the arbitrary lower limit) when the base flow is $X$ cfs. A curve relating base flow to the corresponding volume of live ground-water storage is found in figure 9 . This relation curve was used in a reservoir-type routing procedure to obtain 


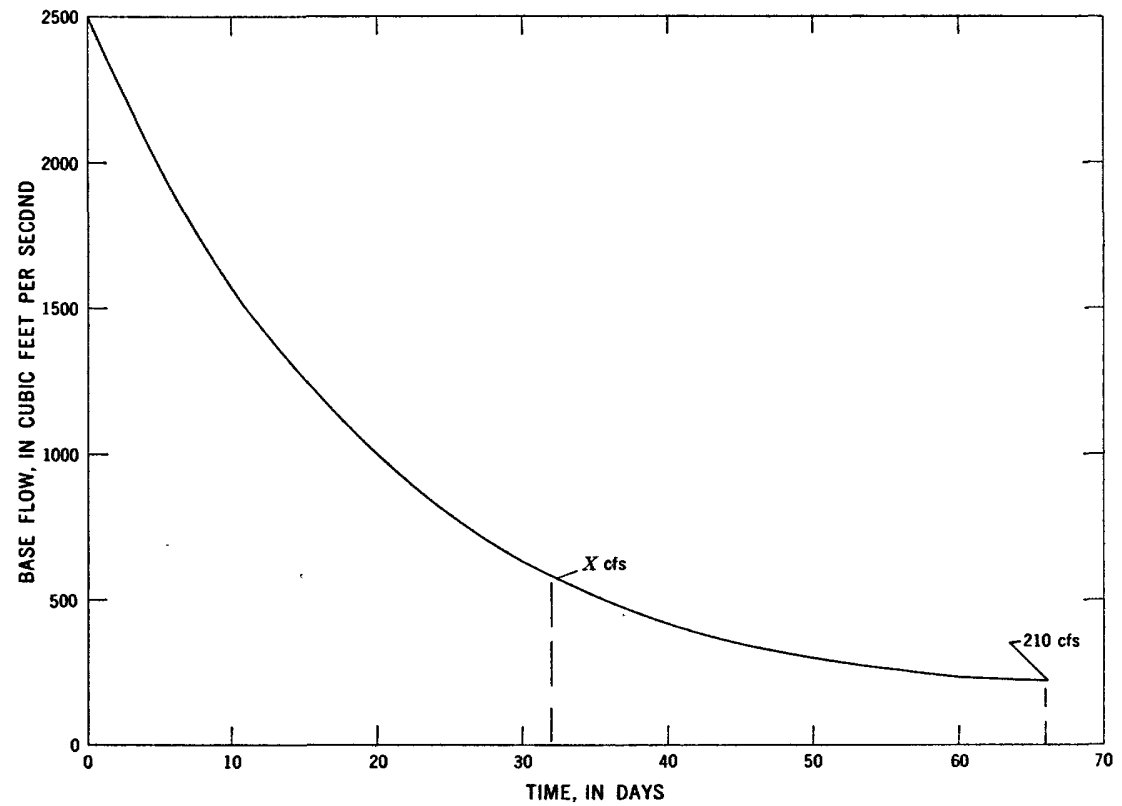

Figure 8.-Base-flow recession curve for North Yuba River below Goodyears Bar.

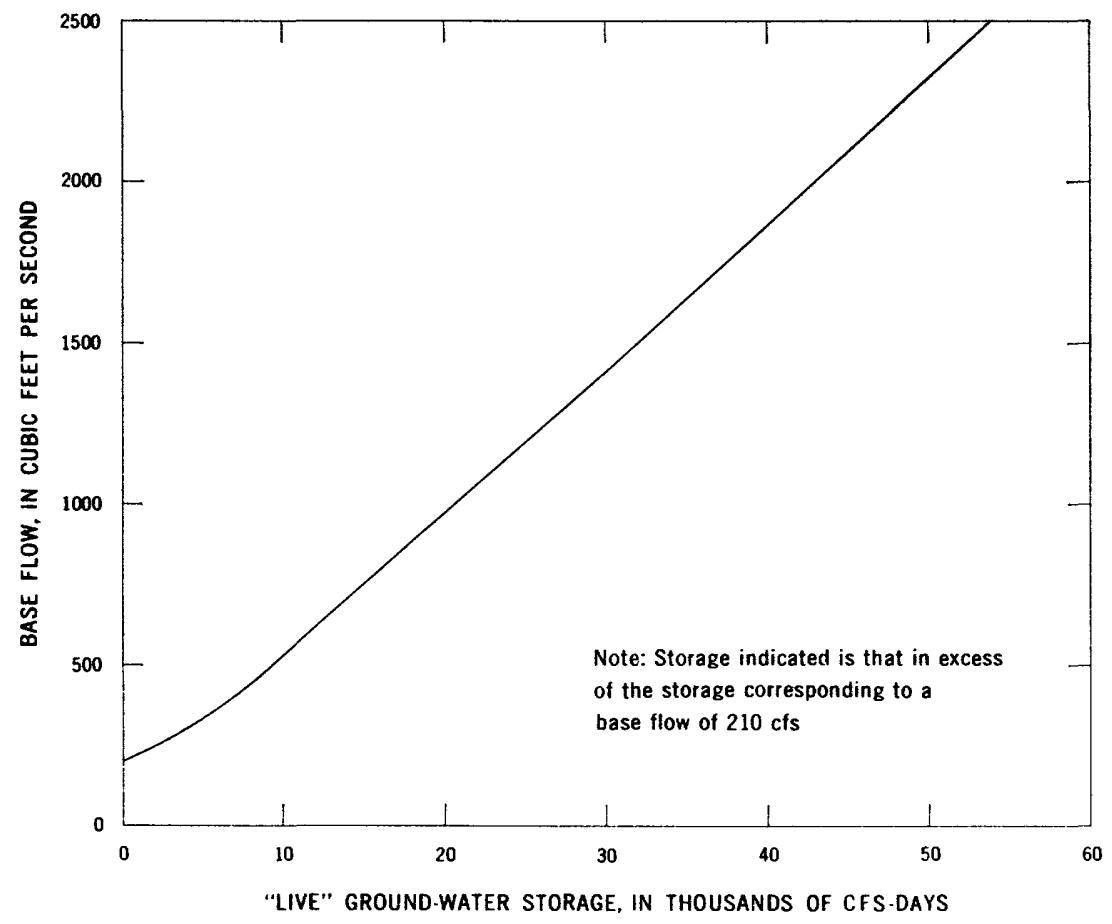

Fioure 9.-Relation of base flow to volume of "live" ground-water storage. 
the base flow resulting from each daily increment of supply that reaches the ground-water body. This type of routing is familiar to practicing hydrologists; for details the reader may consult any standard hydrology text.

The two preceding paragraphs refer throughout to the daily increment of supply that reaches the ground-water body. A time lag exists between the infiltration of snowmelt or rain and the arrival of this infiltrated water into the ground-water reservoir. By trial-anderror it was found that a time lag of 5 days gave best results, and this figure was accordingly used in the routing procedure. For example, table 3 shows that on May 1 of the increment to ground water was $0.350 \mathrm{inch}$; in the routing procedure this increment was used on May 6. The use of a 5-day lag makes it impossible, however, to compute base flow for the first 5 days of each snowmelt season. For each of these days base flow was assumed to equal the discharge immediately prior to the start of the melt season. The error introduced by this assumption is probably negligible, in view of the many other uncertainties of the procedure. The computed daily values of base flow for each of the three snowmelt seasons are listed in table 5 .

The next step was to route the surface-water increment of supply to the Goodyears Bar gaging station. For this purpose the unithydrograph principle, or more specifically, the distribution-graph method was used. The distribution graph, a variation of the unithydrograph, is a flow histogram showing the percentages of the total surface runoff that occur in successive increments of time. Because the incremental average percentages define the hydrograph less explicitly than instantaneous flows, the distribution graph is more easily derived than the unit hydrograph. By using time increments of 1 day, the effect of the change in traveltime as the snowfield recedes is minimized. The use of distribution graphs in computing snowmelt is justified because peak rates of discharge are relatively low and estimates of flow volume are usually more important than detailed rates of flow, as, for example, in analyzing the inflow to a reservoir.

Figure 10 is the 24-hour distribution graph that was derived for this study. The value of runoff on the first calendar day (9 percent) is low owing to the fact that very little of the day's snowmelt reaches the snow-ground interface before noon. In deriving the distribution graph no attempt was made to differentiate between snowmelt and rain. The method of applying the graph is similar to that which would be used in a unit-hydrograph procedure; the daily increments of surface runoff are multiplied by the daily ordinates of the distribution graph (percent), and the appropriate products are added. The 


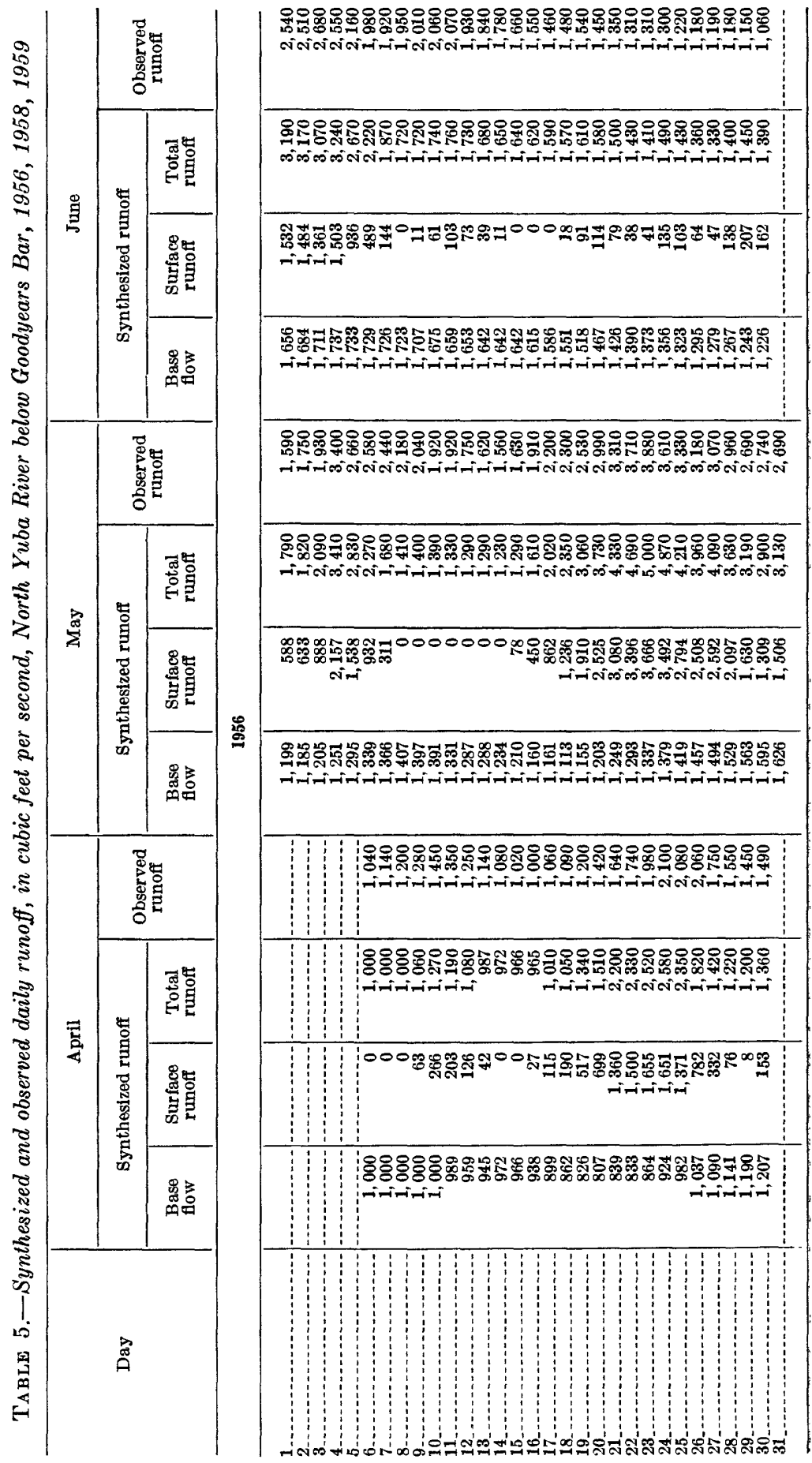




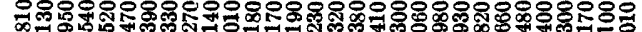

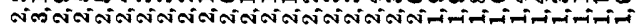

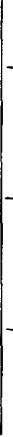

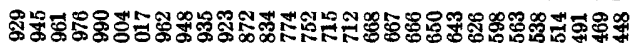

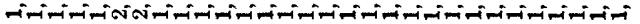

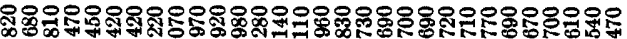

ง

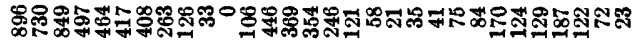

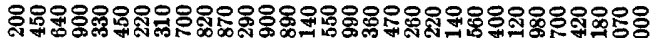

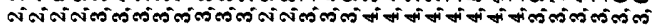

잉్ㅀㅇㅛ

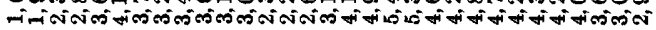

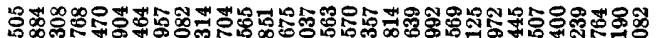

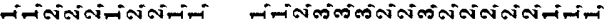

骂

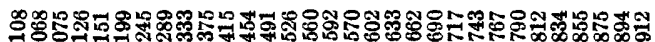

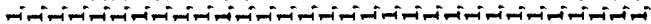

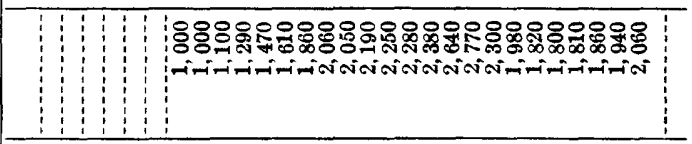

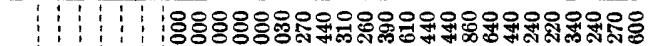

iniminiminiminiminiminiminitinimini

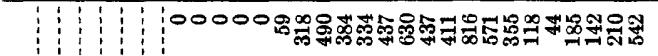

(1)

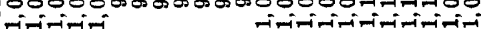

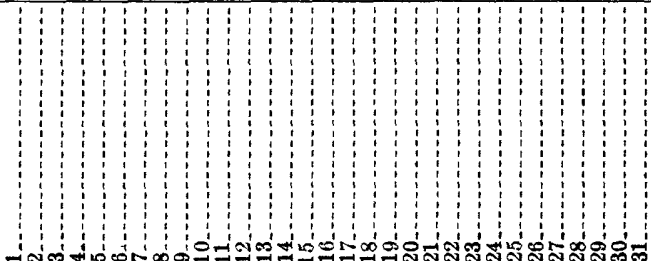




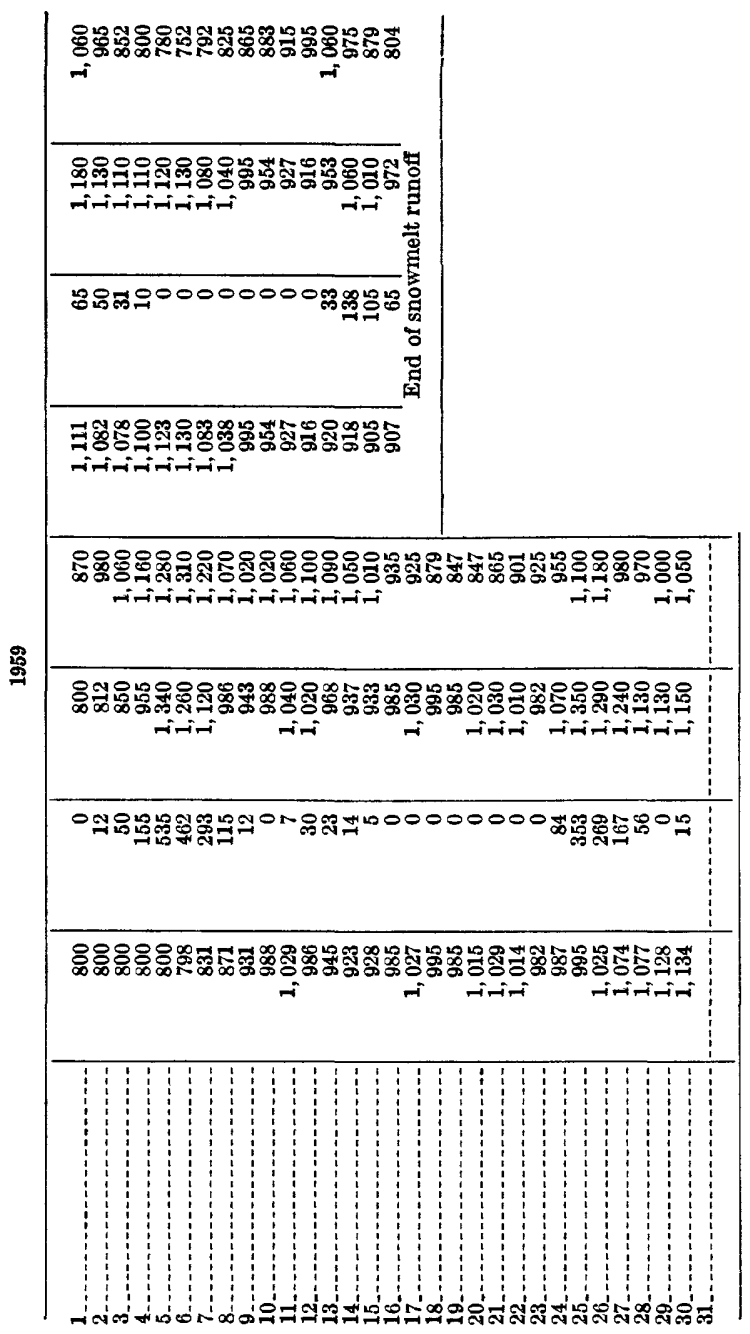




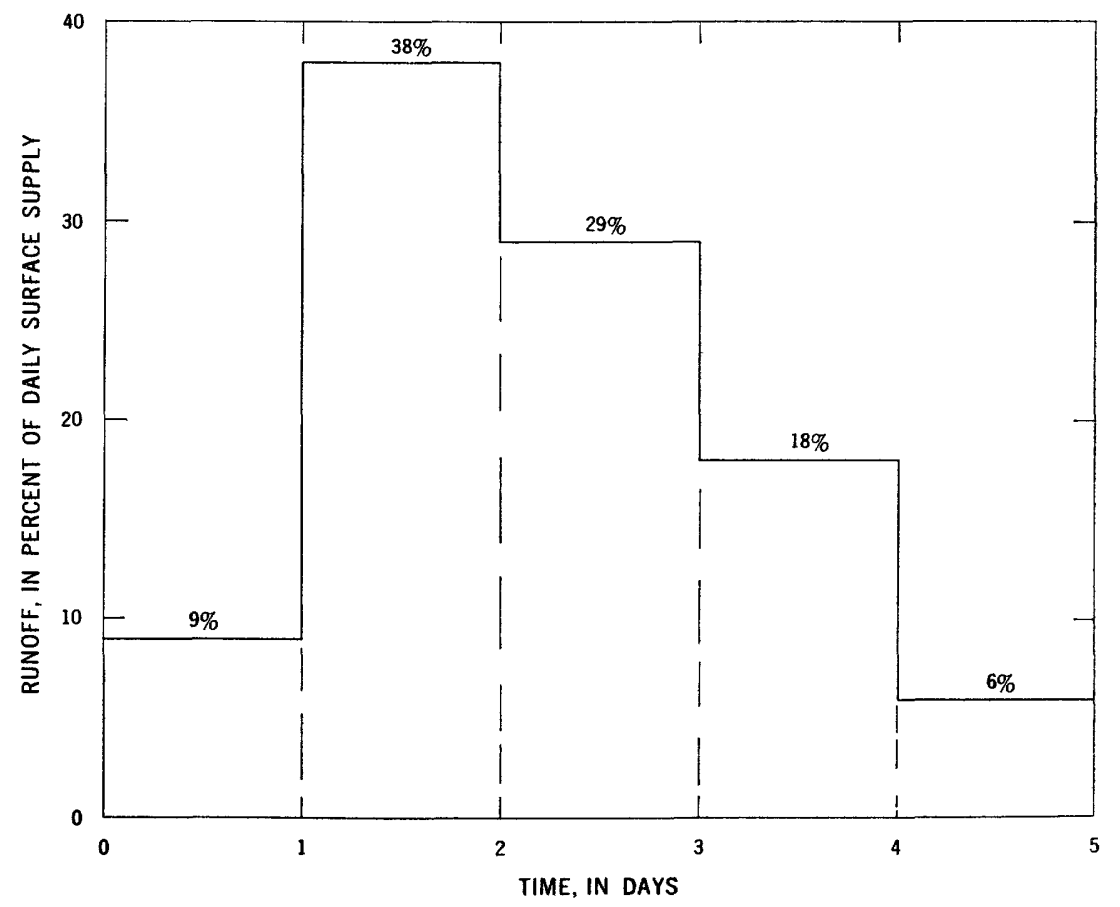

FIgure 10.-Daily distribution graph for North Yuba River below Goodyears Bar.

computed daily values of surface runoff for the three snowmelt seasons have been listed in table 5 , where they have also been added to the base flow to give the synthesized total runoff for each day. Also shown in these tables is the observed mean discharge for each day. The synthesized and observed daily runoff may be compared in the graphs in figure 11.

\section{EVALUATION OF COMPUTED DAILY SNOWMELT RUNOFF}

The graphs of figure 11 indicate satisfactory agreement between the synthesized and observed daily runoff of the North Yuba River, thereby attesting to the soundness of the method used. A factor that undoubtedly limited the accuracy of the computed hydrograph was the paucity of hydrometeorological data. For example, although eight snow courses were used at the start of the snowmelt seasons for determining the areal distribution of water equivalent in the approximately 200-square-mile snowfield, only two of these courses were actually within the study area. This lack of comprehensive snowpack data is especially critical in computing daily runoff when the melting snowpack is very light. At those times the snowfield is 


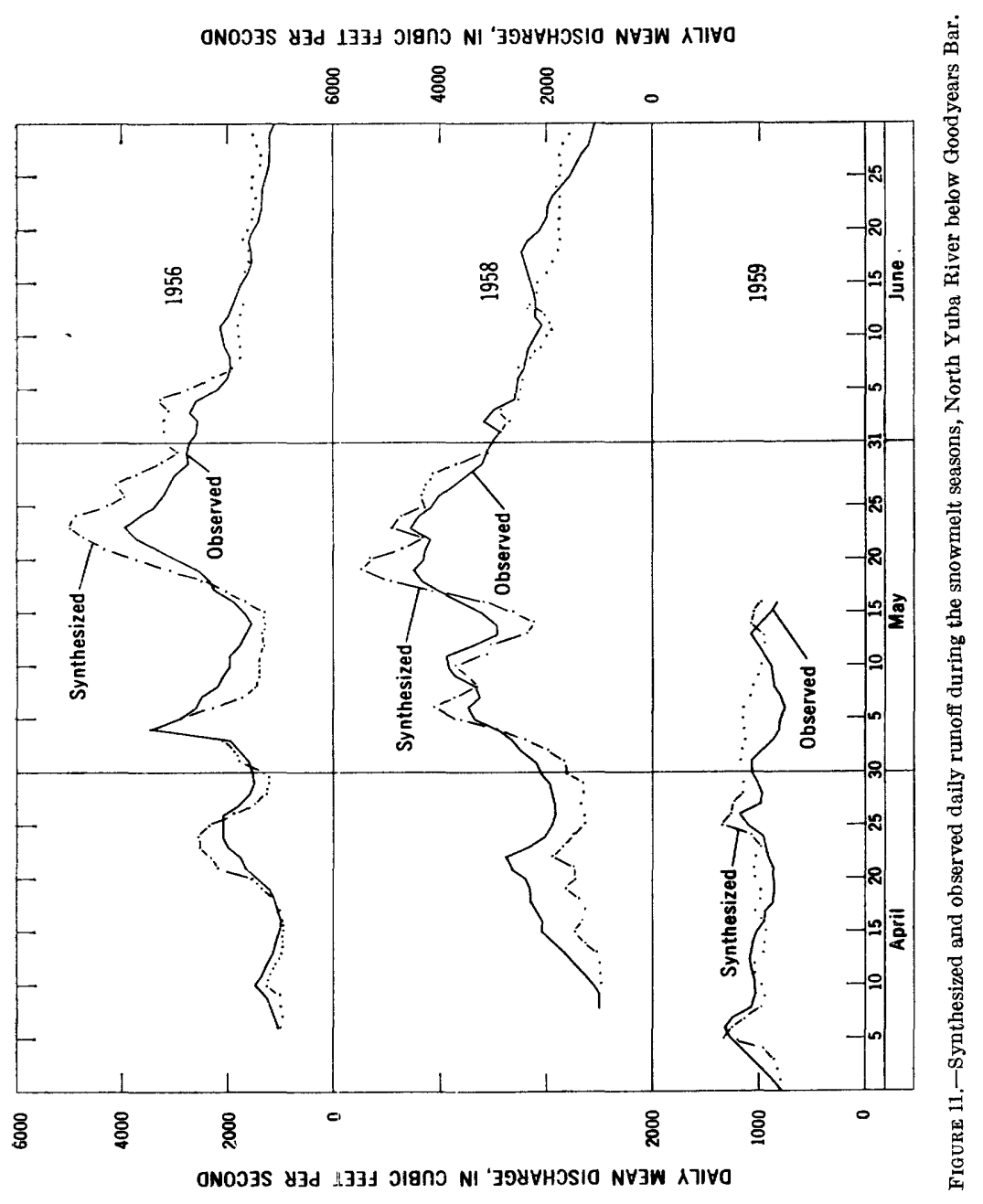


invariably patchy, and the use of only a few snow courses at wellsheltered sites usually leads to an overestimate of daily discharge. Figure 11 shows that this situation prevailed at the end of each snowmelt season, and particularly during the snow-deficient year, 1959, when observed daily mean discharge ranged from a low of 750 efs to a high of only $1,300 \mathrm{cfs}$.

Another very serious deficiency in the basic data was the lack of solar radiation observations in the Sierra Nevada. The method used in this study to synthesize a record of incident radiation for the North Yuba River basin is of limited reliability, and it is quite possible that much of the difference between observed and computed discharge results from inaccurate estimates of this important component of the heat supply. The use of Geological Survey quandrangle maps for estimating forest cover may also introduce considerable error into the computation of snowmelt. The coloring on these maps generally does not delineate forest and brush-covered areas with the precision required.

It is obvious, too, that there may be error in the numerous assumptions that were made in separating snowmelt into its component parts for routing to the gaging station. This type of error is inherrent, however, in any basin-routing procedure that involves the separation of runoff components and is generally not serious. As for routing procedures, it is not to be inferred that the methods used here are specifically recommended for all snowmelt studies of this type. The selection of a simple reservoir-type routing procedure for base flow and a distribution-graph lagging procedure for surface runoff, was influenced by the fact that the accuracy of the estimates of daily snowmelt did not warrant the use of more refined routing techniques. It is a matter of interest that in the wet years, 1956 and 1958, the ratio of computed base flow to computed surface runoff was about 1.7; in the extremely dry year, 1959, this ratio was 14.2 .

Also of interest is the fact that at the close of each snowmelt season, when the river entered the base-flow recession phase of the runoff cycle, the computations showed some snow remaining in the uppermost altitude zone. This is consistent with fact. Remnants of the snowpack invariably exist after the snowmelt runoff season. The melt that subsequently occurs contributes little to riverflow and is eventually dissipated by evapotranspiration.

Getting back to the reliability of the method demonstrated in this report, it is concluded that very good results can be expected from its use in an adequately instrumented basin. Aerial photographs to delineate the areal extent of the snowpack and forest cover would be a most helpful adjunct to the observational program. 


\section{DEGREE-DAY METHOD OF COMPUTING SNOWMELT RUNOFF}

No discussion of the computation of snowmelt runoff would be complete without reference to the empirical degree-day method that has been so widely used in the past. The apparent simplicity of the method is attractive. The average air temperature during a period of melt is considered an index of the integrated effect of radiation and sensible heat exchange. It is further assumed that negligible melting will occur when the air temperature is below some base value, usually $32^{\circ} \mathrm{F}$. The difference, therefore, between the mean air temperature for any given date and the base temperature is the degree-days for that date. For example, using a base of $32^{\circ} \mathrm{F}$, a day with a mean temperature of $49^{\circ} \mathrm{F}$ has 17 degree-days. Degree-days are then correlated with observed snowmelt runoff to provide a temperature index of melt runoff.

A weakness of the method lies in the fact that temperature is generally unsatisfactory as a basin index of the effect of such meteorological elements as wind, humidity, and radiation. Also, the method gives no consideration to the albedo of the snow surface, which may vary considerably with time, particularly as a result of early spring snowfalls. Because the degree-day index is correlated with basin runoff, its evaluation becomes complicated by such hydrologic factors as basin storage and lag, evapotranspiration losses, and the varying areal extent of the snowpack which shrinks as the melt season progresses. It is not surprising, therefore, that the degree-day index for a given basin invariably shows wide variation with time, both within the snowmelt season and between snowmelt seasons. Table 6 lists

TABLE 6.-Degree-day indices of runoff at snow laboratory basins

[Data are in inches of runoff per degree-day from the snow-covered area. Index based on daily mean air temp above $\left.32^{\circ} \mathrm{F}\right]$

\begin{tabular}{|c|c|c|c|c|c|}
\hline \multirow{2}{*}{ Laboratory basin } & \multirow{2}{*}{ Month } & \multicolumn{4}{|c|}{ Degree-day index of runoff } \\
\hline & & 1947 & 1948 & 1949 & 1950 \\
\hline $\begin{array}{l}\text { Upper Columbia } \\
\text { Central Sierra }\end{array}$ & $\left\{\begin{array}{l}\text { April } \\
\text { May } \\
\text { April } \\
\text { May }\end{array}\right.$ & $\begin{array}{r}0.037 \\
.078 \\
.113 \\
.107\end{array}$ & $\begin{array}{r}0.019 \\
.068 \\
.048 \\
.082\end{array}$ & $\begin{array}{r}0.050 \\
.067 \\
.088 \\
.105\end{array}$ & $\begin{array}{r}0.042 \\
.077 \\
.084 \\
.099\end{array}$ \\
\hline
\end{tabular}

values of the degree-day index of runoff at two snow laboratory basins where the hydrologic water budget was studied in detail. (Data for the third laboratory basin were unavailable.) Even in these two basins, where the snow-covered areas were mapped and where con- 
ditions were relatively favorable for its determination, the degree-day index varied widely. No figures were computed for June because of the nonuniformity of the depleted snowpack. It is apparent from this discussion that a more rational approach to the snowmelt problem is needed; the method described in this report should fill that need.

\section{SUMMARY}

This report demonstrates a rational approach to the problem of computing snowmelt runoff. The formulas used in the computation of daily melt have a sound theoretical basis, and the accuracy of the results obtained will depend primarily on the adequacy of the hydrometeorological network in providing the data required in the formulas. After the daily snowmelt quantities have been determined, any of the standard routing procedures, such as the unit hydrograph method, may be used to derive the streamflow hydrograph.

The adequacy of the above methodology was tested, using the hydrometeorological data collected in and about a typical Sierra Nevada watershed, that of the upper North Yuba River. The synthesized and observed hydrographs of daily snowmelt discharge agreed satisfactorily.

\section{REFERENCES}

Anderson, H. W., and Richards, L. G., 1961, Fourth Progress Report, 1960-61, California cooperative snow management research: Pacific Southwest Forest and Range Experiment Station, U.S. Forest Service, 110 p.

Hamon, R. W., Weiss, L. L., and Wilson, W. T., 1954, Insolation as an empirical function of daily sunshine duration: Monthly Weather Rev., v. 82, p. 141-146.

U.S. Army Corps of Engineers, 1956, Snow hydrology, Summary report of the snow investigations: North Pacific Division, Portland, Oreg., 437 p.

U.S. Army Corps of Engineers, 1960, Runoff from snowmelt: Eng. Manual 1110-2-1406, $59 \mathrm{p}$. 